\title{
PAUL'S CONCEPT OF SALVATION - CULMINATION OF AN EVOLUTIONARY PROCESS
}

\author{
Klaus Nürnberger \\ University of Natal
}

\begin{abstract}
This essay is an attempt to demonstrate that Paul's concept of salvation is the culmination of a long evolutionary history in biblical times. The nature of the "law" moved from an unspecified kind of faithfulness (zedaqah), through rather rigid and increasingly elaborate apodictic, casuistic and ritual formulations, to common wisdom and finally an open kind of motivational renewal "in the Spirit". The contents of the law changed substantially from rather authoritarian to increasingly participatory forms. The relationship between God and humans moved from a gratuitous relation between a superior and a subordinate, through the conditionality of the covenant to God's unconditional but transforming acceptance of the unacceptable in the theology of Paul. God's redeeming acceptance into his fellowship restores the relationship of sinners with God and brings about their transformation. Paul's soteriology is characterised most profoundly by the eschatological transition of the human being from "flesh" (or this age) to "Spirit" (or the age to come), anticipated in faith through the power of the Spirit, rather than by the doctrine of justification. Paul's disciples were not able to maintain these lofty thoughts, nor was Paul himself. The essay closes with a few instances which demonstrate the decisive and pervasive relevance of the distinction between conditional and unconditional acceptance in modern society.
\end{abstract}

\section{Introduction}

This paper is part of a hermeneutical research project in which I trace the evolutionary trajectories of soteriological paradigms in biblical history - patriarchal promises, ${ }^{1}$ exodus and conquest, ${ }^{2}$ king and empire, ${ }^{3}$ priesthood and sacrifice, ${ }^{4}$ covenant and law, ${ }^{5}$ creation and eschatology ${ }^{6}$ - and extrapolate the thrust of their undercurrents of meaning to contemporary issues. ${ }^{7}$ In virtually all cases an inversion, or at least a supersession, of the original paradigm emerged from these analyses.

When we come to the paradigm of covenant and law in the Old Testament, or grace and law in the New Testament, we enter into the holiest of holies of the biblical faith, its innermost core, and its deepest foundation. Redemption is the very rationale of the biblical faith and, according to the biblical faith, redemption depends on the restoration of a healthy relationship between God and human beings. Other concerns, such as spiritual excellence,

1. Nürnberger 1993a.

2. Nürnberger 1999 a

3. Nürnberger 1992.

4. Nürnberger 1999b.

5. Nürnberger 1993b.

6. Nürnberger 1997.

7. The whole exercise is to be published in 2001 by Cluster Publications, Pietermaritzburg, under the probable title Evolutionary Hermeneutics. 
intellectual enlightenment, political liberation, social equity, and ecological sustainability are necessary derivations, but not the foundation.

The relation between faith and obedience in Paul's theology represents the most elaborate form of the inversion of the covenant-law paradigm in the New Testament. We shall begin, therefore, with a brief sketch of the evolutionary trajectory of the covenant-law paradigm leading up to Paul's theology. Such a sketch cannot do justice to the scriptural evidence and a massive scholarly discussion, which are catered for elsewhere. ${ }^{8}$

We distinguish between the nature of the law, the relation between divine commitment and human obedience, and the contents of the law. Then we analyse Paul's version, together with its intricacies and inconsistencies, and close with a brief indication of how his stance was modified by his disciples.

\section{The historical evolution of the paradigm in the Old Testament}

The evolution of the nature of the law

Behind the notion of the covenant lies the vision of shalom (peace), which I define has comprehensive well being. God is taken to be the creator and redeemer of humankind in general and Israel in particular. The mastery, benevolence and vision of God find expression in a covenant which formalises and particularises Yahweh's commitment to Israel, his people, and spells out its consequences for Israel. ${ }^{9}$

In the Ancient Near East this kind of covenant was not deemed to be a contract between equal partners, but the provision made by an authority for its subordinates. Yahweh's commitment called for a response from his people which would express the involvement of Israel in the creative and redemptive intentions of God. ${ }^{10}$

Originally the human response to the divine covenant was nothing more than common decency as defined by, and internalised in, a patriarchal-hierarchical order. Zedaqah (righteousness) was understood to be an attitude and behaviour appropriate to a relationship of shalom between the partners. This form of the "law" can be found in the patriarchal narratives especially the story of Abraham, the "father of faith".

However, an internalisation of values and norms presupposes that they have been formulated in some form in the oral or written tradition. This formulation can be called the apodictic law. ${ }^{11}$ It defines the prerequisites and boundaries of wholesome existence under the umbrella of the covenant. ${ }^{12}$

Because humans do not always keep within the boundaries of wholesome existence, legal processes have to be institutionalised. Legal procedures before a court of law presuppose that acceptable behaviour is defined and that the consequences of unacceptable behaviour be spelt out. This leads to the casuistic law. As Israelite society grew in size and complexity, increasing elaborations of acceptable behaviour became necessary. In contrast to modern secular society, all these elaborations were subsumed under the terms of the covenant thus carried divine sanction and authority.

At this juncture we have to make another distinction. On the one hand we have the world-view of grass roots communities, loosely organised in clans and tribes who were,

8. In the volume Evolutionary Hermeneutics mentioned above.

9. Smend 1963.

10. See Sanders 1992:262ff on "covenantal nomism" as the centre of the Jewish faith.

11. Alt's work has often been critiqued (Gerstenberger 1965; Liedke 1971). However, the basic distinction between apodictic and casuistic law is still useful.

12. Cf Boecker 1980. 
given a chance, fiercely independent. In as far as grass roots communities are the prime victims of natural disasters and political ruthlessness, this version of the law is interested in change and therefore tends to be future oriented, and ultimately eschatological.

Ruling classes of the Ancient Near East, on the other hand, propagated the notion of a cosmic order which encompassed the moral, social and natural dimensions of the universe. Moral trespasses or political insubordination could lead, therefore, to natural catastrophes. This order was believed to have been established by the Deity and to be administered by the king, the representative and plenipotentiary of God on earth. ${ }^{13}$ The notion of the cosmic order betrays the interests of a ruling elite in stability; it is thus a conservative worldview which is quite naturally based not on eschatology but on protology (creation). An Israelite version of this approach, originally derived from Egypt, is found in Psalm 2.

However, the royal-imperial paradigm changed into the vision of a "true king", who would change the current oppressive order and bring about universal justice and prosperity. This messianic version of the royal-imperial paradigm entrenched itself so powerfully in Israelite-Jewish consciousness that it survived the demise of the Israelite kingship, informed the messianic-apocalyptic expectations of Judaism and became central in early Christianity.

The casuistic law and the notion of the cosmic order sorted out conflicts among people and helped to establish a stable society. But it could not deal with the root cause of evil, whether in the form of imperial subjugation, the pangs of fate, or the irregularities of nature. The root cause of such calamities was perceived to be the discrepancy between divine intentions and human motivations. The human partner had to acknowledge divine right and human obligation. This demanded repentance, satisfaction, restitution and reconciliation.

All these seemed to call for symbolic acts, such as sacrifice, fasting and purification. Initially such acts were spontaneous and presided over by family heads. In time they became formalised, institutionalised and functionalised to serve the interests of ruling elites. An increasingly elaborate and grotesque ritual law evolved which the priesthood at the sanctuary administered. ${ }^{14}$

During the post exilic restoration a cultic community was set up in Jerusalem. The emphasis shifted from moral excellence to cultic purity. ${ }^{15}$ Yahweh and his people were defined in terms of holiness and holiness was defined in terms of a "setting apart" of special times, places, offices, objects, fruit, animals, people and patterns of behaviour. "You must distinguish between the holy and the common, between the unclean and the clean (Lev 10:10). Sanctity was now defined not by justice but by taboo.

At the same time the law was codified and absolutised. It no longer formulated the prerequisites of wholesome communal life in changing situations and appropriate responses to dangerous patterns of behaviour, but a divine decree which had to be observed whether it made sense or not. In this rigid form the law became the mediator of divine presence, thus the entity to which believers primarily related. This law became a formidable means of control in the hands of priests and teachers like the Pharisees.

The absolutised law also became one of the driving forces of revolutionary fervour and apocalyptic expectations. The Makkabean rebellion against Hellenistic rule was sparked off by the encroachments of Hellenist rulers upon Jewish religious taboos and sacred

13. For detail see Nürnberger 1992.

14. Nielsen 1982:88 shows that in J the law comprises of half a chapter, in E 3-4 chapters, in D 15-16 chapters, in P more than 70 chapters.

15. Theissen depicts holiness as a means of social control in Judaism 1999:107ff. 
institutions. The Jewish martyrs were convinced that one had to lay down one's life to uphold the sanctity of the torah. The withdrawal of the Essenes into the desert was based on similar motives.

The complexity of the torah and its prolific interpretations led to attempts to recapture the gist, or the basic rationale, of the torah. The so-called shema (Deut 6:4ff) is probably the most important of these summaries, followed by the introduction to the decalogue. ${ }^{16}$

The summaries are capable of breaking open legalistic rigidities because under their umbrella the detailed formulations are taken to be mere examples of righteous, loving or redeeming behaviour.

A more radical departure from an absolutised law is found in Wisdom literature. Law is decreed, wisdom is discovered. Its concrete injunctions are derived not from fundamentalist assumptions, such as a sacred story or a divinely ordained code of conduct, but from an assessment of the requirements of successful daily living. Aiming at moral maturity rather than slavish obedience, it appeals to experience, observation and common sense rather than revelation. ${ }^{17}$

In metaphysical terms, wisdom was believed to underlie the very rationale of reality as a whole, ${ }^{18}$ similar to the "cosmic order" of old, or the torah, or the Greek concept of the logos. In Proverbs and Sirach, wisdom became hypostatised, even personalised, as the mediator between the Creator and the creation, between humanity and its well being (Prov $8: 22-32 ; 1: 4,8-10$; Sir 24; Bar 3:9-14). Though lip service is often paid to the torah, we find a subtle substitution of wisdom for the torah.

The motive of redeeming love became fundamental in all the main streams of Christian theology. The synoptic Jesus filled his proclamation and enactment of the coming Kingdom of God with the content of redeeming love. Not abstract formulations, rituals or taboos, but redemptive responses to the needs of the sick, the outcast, the guilty, the demon possessed, the hungry, the powerless, the crippled characterised his behaviour. Without doubt this included his confrontation with entrenched structures which used the law to oppress and exploit the people for their own ends and which brought him to the cross.

But early Christianity was not of one mind concerning the validity and character of the law. None of them upheld the sacrificial laws. ${ }^{19}$ But that is where the consensus ends. The Synoptic Gospels have a discipleship-ethic. Matthew claims that the Jesus movement is more meticulous in keeping the law than the Jewish spiritual leaders. John concentrates on God's self-giving love in Christ in which believers get involved. The conflict of Paul with Jews and Jewish Christians, notably with Peter (Gal 1-2), concerning the law is well documented. ${ }^{20}$ Paul never relativised righteousness as the goal of the redemptive action of

16. Levenson 1976:73: According to rabbinic theology, the 613 laws of the Pentateuch were compressed into 6 in Is 33:15f, into 3 in Mi 6:8, into 2 in Is 56:1 and Amos 5:4 only one - matched by Hab 2:4. Rabbi Akiva says that Lev 19:18 "love your neighbour as oneself" is the "great rule". However, the full range of the commandments still has precedence over the summary! In Paul Rom 13:8-10, or modern Christian thought, it is the other way round.

17. Theissen sees Wisdom located in the upper classes, which would probably have had some freedom from the priestly caste 1999:101ff.

18. Gese speaks of a "melting of the Torah with the cosmic law" which came on the scene with "sapietialization" (Räisänen 1995:229). This presupposes that the torah and wisdom are essentially the same thing, which can be disputed.

19. Theissen believes that the class and ethnic definition of holiness is done away with in the Jesus movement and in early Christianity: every believer was now a "saint" and given the status of a "priest" (1 Pet 2:9) (1999:109ff).

20. Found in 1 Thess 2:14-16; Gal; Phil 3; Rom 1-8. 
God, but did not link this righteousness with the formulations of the torah. What matters for him is the crucifixion of the flesh and the "fruit of the Spirit" (Gal 5:22ff).

To sum up, what we call the law has gone through an evolutionary process and produced a variety of forms, not all of which are equally wholesome and theologically acceptable. One can distinguish between three major trends, one towards stability and obedience, the second towards ritual purity and the last towards freedom and responsibility in the face of changing situations.

\section{The evolution of the relation between covenant and law}

As mentioned above, the law originally defined an attitude and behaviour which falls in line with the prerequisites of human well-being. What is at stake under this new topic is the logical sequence between divine and human initiative. In its crudest form the human act of obedience can either be perceived to be the precondition for the divine act of grace, or the human act of obedience can be taken to be a consequence of the divine act of grace. Within the second alternative one could again differentiate between conditional and unconditional acceptance into God's fellowship. The latter implies that God suffers the unacceptability of those, whom he accepts, not to condone, but to overcome it.

The most revealing metaphor found in the Old Testament for the relation between divine and human initiatives is the marriage between Yahweh and Israel. In a patriarchal society it is the groom who elects his bride; the bride is expected to submit to this "act of grace" in faithful obedience to her husband. Adultery carried the death sentence. In view of the alleged unfaithfulness of Israel, we should not be surprised that the prophets announced the "death" of the elect people of God.

The occasions which led to such a verdict were experiences of extreme hardship, injustice and oppression, especially the destruction of Samaria and the Kingdom of Israel by the Assyrians in 721 BC. In the South it was easy to argue that God had punished (Northern) Israel for treason and apostasy, a fate which could not possibly happen to Jerusalem. The prophets debunked this message as religious self-deception which created a false sense of security. And indeed Jerusalem fell to the Babylonians in 587 BC.

The national catastrophes cast the Israelite faith into a mortal crisis. What had become of the commitment of Yahweh to his people? Either he was not willing to help; then he was not the trusted God of the covenant he was assumed to be. Or he was not able to help; then he was not the master of heaven and earth that he was believed to be. A powerless God is a useless God. The prophets turned the argument around: not Yahweh had been unfaithful but Israel. Yahweh, in his righteousness, had turned against Israel, because Israel had broken the covenant.

This message was unpopular and unpleasant at the time, but it saved Israel's faith by reinforcing the link between righteousness and well-being. Zedaqah is human correspondence to, or participation in, divine commitment to comprehensive well-being. Where the appropriate attitudes and behaviour are not forthcoming, righteousness is posited explicitly as an obligation. If that does not lead to a satisfactory response, the demand turns into judgment.

The consequence of this line of reasoning was that the gratuity of the covenant became, in fact, conditional upon an appropriate response of the human partner. ${ }^{21}$ Conditionality is

21. In Ex 19:4-6 "God promises a special covenant relationship, conditional on obedience by the people ... disobedience leads to divine wrath, punishment being the converse to blessings, both being built into the covenant" (Christiansen 1995:48f), 
indicated by the "if - then" formula. Picking up on the prophetic message, the deuteronomic tradition spelt out the alternatives in the starkest possible terms: if you keep the law meticulously and in its finest detail you will be blessed; if you transgress the law you will be cursed. There is no middle way (Deut 11:26ff; 28:1ff; 30:15ff).

Because the two national catastrophes of 721 and 586 seemed to have vindicated the prophetic and deuteronomic message, the link between sin and suffering became accepted orthodoxy in exilic and post-exilic times. But the negative notion of a failed covenant was unhelpful in the arduous task of consolidating a Jewish identity after the great dispersion. The returnees from Babylon, the less than enthusiastic am-ha-arez who had continued to live in Judea, as well as the remnants of the nation scattered all over the Ancient Near East had to be bound together by common symbols, rituals and spiritual leadership.

The law now served to maintain the boundary between in-group and out-group, keeping those outside out, and those inside in. ${ }^{22}$ Because of the precarious political situation, they had to be applied more rigorously than ever to establish not only external boundaries to separate Israelites from Gentiles, but also internal boundaries to separate the pure and holy from the impure and unholy within Israel. ${ }^{23}$

To counteract failures, appropriate rituals of atonement were instituted which made it possible to continue living under the shadow of Yahweh's benevolence in spite of being a stiff-necked people - rituals which, incidentally, also provided a lucrative source of income to the priestly caste.

Legitimation has to be grounded in a comprehensive system of meaning. Following some Babylonian leads, the Priestly school drew up a grandiose world-view. God had constructed the universe in the midst of chaos (Gen 1), commissioned the human being to be in charge of the world, committed himself never again to demolish it as he had done during the flood, chosen Israel to be a sacred people, given the law, established the place of his presence on Mount Zion, and commissioned the priesthood to mediate between himself and the people. All this represented a cosmic order which had found its earthly peak in a holy time (the Sabbath), a holy place (the Zion), a holy pattern of behaviour (the law), a holy set of rituals, administered by a holy caste of priests, all belonging to a holy people.

The assumption was that all this was "very good" (Gen 1). To be richly blessed, Israel only had to set itself apart and assume its role as God's own people. In a subtle way, the logical order between covenant and obedience was reversed: if Israel kept the law Yahweh would grant the covenant. ${ }^{24}$ The law was primordial; the covenant depended on observance of its stipulations. The religious life of a holy people mirrored the law, and the law mirrored the cosmic order.

22. Cf Eph 2:14f. (The common Jewish understanding (was) "getting 'in and staying in' the people of God." Sanders 1992:262.

23. Gese 1977:63ff believes that the Assyrian Empire with its transnationalism forced the Israelite faith into personal commitment (in Deuteronomy) and out of nationalistic particularism. Nothing could be further from the truth!

24. Gen 17:1 (P) reads: "I am El Shaddaj; walk before me and be 'whole' (= blameless) and I will institute my covenant between you and me and greatly increase your numbers". In Jub 15:1ff Abraham first brings the sacrifices appropriate for the festival of the first fruits; upon which Yahweh appears to him saying: "I am El Shaddaj; acquire favour before me and be whole, and I will institute my covenant between you and me and make you very great." Also in Sir 44:19 keeping the law logically precedes the covenant: "(Abraham) kept the law of the Most High and entered into a covenant with him; he certified the covenant in his flesh (circumcision) and when he was tested proved faithful". In line with the greater moral autonomy of Wisdom literature, the initiative moves to the human partner! 
But calamities persisted. The assumed disobedience of Israel remained deeply puzzling. Yahweh had to intervene on that level. Deuteronomy envisages a "circumcision of the heart" (Deut 30:6). Jeremiah 31:31ff envisages a new covenant. Yahweh would pour his Spirit into the heart and mind of every Israelite (Joel 2:28f; Ez 37:14). Yahweh would give them "a new heart and a new spirit", not a heart of stone, but a heart of flesh (Ez 11:19f; $36: 26) .^{25}$

The transformation of human motivations was believed to be a sovereign act of the Creator. Yahweh had to take over responsibility not only for his side of the covenant, but also for the side of Israel. The activity of God does not exclude, but includes the activity of the human being. Though Yahweh promises to give Israel a new heart and a new spirit, he exhorts Israel to "get a new heart and a new spirit" (Ez 18:31). This dialectic foreshadows Paul's enigmatic formulation in Phil 2:12f: "work out your salvation ... because it is God who is at work in you..."

The prophetic and deuteronomic movements had established a causal link between Israel's calamity and Israel's sin. But not all Jews found the argument convincing. Nor could their spiritual agony be pacified by ritual observances. Psalm 44:17-21 flatly denies that Israel had brought the predicament upon its own head through its unfaithfulness to the covenant. The book of Job documents the agonising struggle to find alternatives to deuteronomic orthodoxy on the side of those who deemed themselves innocent.

If Yahweh was indeed a God of justice, and if he was indeed in charge of the situation, why should the people of God who had tried to keep the law to the best of its ability, be smashed to pieces, while its brutal pagan oppressors, who manifestly had not the slightest respect for God's will, were allowed to conquer and prosper? Why should those individuals among the Israelites who had acted justly perish together with those who had led loose lives? If Israel had indeed sinned, was Yahweh's punishment not completely out of proportion with Israel's failures? And if God had committed himself to his people, why can he not forgive? In short, it was not only the righteousness of the believers that was at stake, but also the righteousness of God.

In the Book of Job there are three approaches to the question of God's justice. In the opening chapters, Job's suffering is derived from the fact that Satan, Yahweh's public prosecutor, was over ambitious in his task to test the faithful (Job 1-2). In the body of the book, Job rejects the (orthodox) view of his friends, pleads his innocence, and demands that divine justice be done (Job 29-31). In the closing chapters the message is: Yahweh is too great for us to understand his ways!

This could have been the recipe for fatalism, if the book did not end on a hopeful and redemptive note: all the fortunes of Job were, in the end, restored to him! In some way all attempts to make sense of a desperate situation appeal to the future. For a theology that builds on the conviction that God is a God of justice, eschatology is, ultimately, the only logical way out. If justice is not seen to be done, then God must have made plans for the future. That is the root of eschatological hope.

By the time of the exile, the idea of corporate accountability began to make way for individual accountability (Deut 24:16; Jer 31:29f; Ez 18:1ff). God's justice could not be limited to the boundary of life which God himself had set. It led to the conviction that the dead would be raised to face ultimate judgment. Note that it is not a longing for immortality

25. For an analysis of Ez see Christiansen 1995:59ff. While Jeremiah's new covenant was still a covenant of the people, Ezekiel "takes renewal a step further ... in the direction of individualisation." 
which informed this development, but faith in the mastery of a God of justice over sin and death. But the notion of resurrection remained controversial in Judaism. ${ }^{26}$

Individualisation went along with universalisation. Through the encounter with Babylonian mythology, at the latest, the Jewish faith had acquired cosmic horizons. Through the encounter with Persian religion, the Jews acquired a sense of cosmic history. Resurrection from the dead now coincided with the advent of the new age; the last judgment became Yahweh's means to overcome evil once and for all. The reward for righteousness became participation in a new life; the punishment for sin became the "second death" of being thrown into the fiery pool.

When these anticipations of future history were impacted by the Hellenistic preoccupation with timeless validity, they acquired a more sinister character: while authentic life became eternal life, the eradication of sinners in a fiery pool became eternal torment.

In the New Testament the concept of the covenant is extremely rare, while the concept of election is not. Where the concept of the covenant is used at all, it is used to claim that the gospel of Christ fulfilled or superseded what it considers to be an old and now obsolete dispensation. $^{27}$

The concepts of grace and love have taken the place of covenant and law as foundational concepts in God's relation to humans. My guess is that the particularist and conditional character of the covenant-law paradigm did not fit the Christian faith experience and obstructed the accessibility of God's salvation in Christ to all people, whether Jews or Gentiles. ${ }^{28}$

We shall come back to that below.

To sum up, the relation between divine and human initiative in bringing about righteousness has evolved through the following stages: righteousness as a kind of common decency implied in any covenant relationship; definition of the boundaries of acceptable behaviour within a covenant relationship; laws and sanctions applicable to particular transgressions; taboos and exclusions to achieve a pure society; hope for a creative act of God to transform human hearts; holding Yahweh rather than Israel responsible for Israel's calamities, hope that Yahweh would bring about cosmic transformation; a new motivation of love created by faith in Christ's death and resurrection in the power of the Spirit.

26. For Sirach 41 the finality of death is a degree of God, which one should accept, while the Wisdom of Solomon 1-3 argues that the denial of resurrection is due to the opportunism of sinners. Job 14 too rejects resurrection as a way out of the problem of theodicy. For Judaism during NT times see Sanders 1992:298.

27. Apart from Acts 3:25; 7:8, there are three main occurrences: (a) all four versions of the words of institution of Holy Communion speak of "the new covenant" picking up the only occurrence of this concept in the Old Testament, namely Jer 31:31; (b) Paul contrasts the covenant of the letter with the covenant of the Spirit and their respective ministries (2 Cor 3:6ff.) and (c) the Letter to the Hebrews develops an elaborate theology of the obsolescence of the old covenant and the institution of a new one mediated by Christ (Heb 7:22; 8:6 $8: 13 ; 9: 15 ; 12: 24)$. In Heb $13: 20$ we have the curious reference to "the God of peace (shalom) who brought again from the dead our Lord Jesus ... through the blood of the everlasting covenant". The rest of the Letter makes clear, however, that this "everlasting covenant" is rooted in the promise given to Melchizedek, thus to Christ, not in the one given to Israel (Heb 5-7).

28. Sanders believes that Paul rejected the necessity of circumcision for salvation because the latter would have implied that Gentile converts had to become Jews. My contention is, rather, that it would have made acceptance conditional. 


\section{The evolution of the contents of the law}

The contents of the law also underwent an evolutionary process during the millennium of canonical history. Here I can be brief because I can refer to previous studies. This evolution often led to an inversion of the original. Here are a few examples.

The family law:

In Exodus 21:1-11 we find an old Israelite law which expresses and legitimates the patriarchal structure of the time. A father can sell even his own daughter into slavery, buy a slave girl as a wife for himself or his son, and give a slave girl as wife to a male slave. In the latter case property rights on slaves override the marriage bond, because if he gains freedom, she does not. The inversion is found in Gal 3:28 (in Christ there is no Jew or Greek, slave or free, male or female). ${ }^{29}$

This statement is based on the new relationship between God and humans (Gal 3:234:11). As we shall see below, neither Paul nor his disciples were able to uphold this revolutionary insight in practice.

The law on royal prerogative: ${ }^{30}$

In Psalm 2 we find the religious legitimation of imperialist subjugation and brutal autocracy. The divine autocrat in heaven adopted the human autocrat on earth as his son, thus as his representative and plenipotentiary on earth. The inversion is found, for instance, in Mk 10:35ff par. Here Jesus calls the model of Psalm 2 pagan and demands of a leader that he be the slave of his/her subordinates as Jesus himself had been. ${ }^{31}$

The citizenship law: ${ }^{32}$

In Exodus 23:20ff and Deut 7 the original inhabitants of Canaan were to be oppressed and rooted out mercilessly by the invading Israelites; Yahweh is perceived to have commanded even genocide to keep the people of God pure of heathen abominations. The inversion is found, for instance, in Ephesians 2. God's unconditional acceptance (2:4-10) leads to the dismantling of "the wall of hostility", that is, the law, which had separated Gentiles from Jews and the formation of a single humanity.

The sacrificial law: ${ }^{33}$

According to Exodus 13:2 (Ex 22:29f; 34:19; Nu 3:13; 8:12ff; 18:15ff) every firstborn male, whether human or animal, had to be sacrificed to Yahweh. In time substitutes were instituted (first an animal, then the blood of the animal). Finally the entire paradigm had turned upon its head. Now it was God who had given his firstborn Son as a sacrifice to humanity (Rom 3:25; Jn 3:16; 1 Jn 2:2; 4:10; cf Gal 1:4; 2:20; Eph 5:2). ${ }^{34}$

29. A rudimentary inversion of this rationale can be noticed in Gen 1:27f (male and female humans have both been created in the image of God, thus as kings and queens - see Nürnberger 1999 for detail). This text was a protest against the Babylonian myth of creation (the Enuma elish), which said that humans have been created as slaves for the gods (thus the imperial authorities).

30. For detailed research see Nürnberger 1992.

31. Reviv 1987:567ff shows how the elders gain progressively more power and status.

32. For detailed research see Nürnberger 1999a.

33. For detailed research see Nürnberger 1999b.

34. For further details of the inversion see Theissen 1999:139ff. 


\section{Faith and obedience in the theology of Paul}

\section{The basic framework}

To begin with, three basic considerations. First, Paul's theology underwent a distinct evolutionary process from his earliest letter (1 Thess) to his latest (Rom / Phil) which continued in the Deutero-Paulines ( $\mathrm{Col}$ and Eph) and the Pastoral Letters (Tim, Tit). We restrict the following discussion to the letters accepted to be Pauline by critical scholarship.

Second, Paul's letters were not written as theological treatises but spontaneous reactions to problems emanating from his congregations or his missionary activity. ${ }^{35}$

This means that his concepts and thoughts are not necessarily consistent throughout his work, but respond freely to the situation at hand. They are also based mainly on existential analysis rather than theological speculation.

Third, in my view the discussion on Paul's theology has been bedevilled by the fact that the controversies during the Reformation concentrated on the doctrine of justification. ${ }^{36}$ Paul could not avoid the legal metaphor if he wanted to refute the law-based Jewish tradition, ${ }^{37}$ just as Hebrews uses the sacrificial metaphor to refute the sacrifice-based Jewish tradition. ${ }^{38}$ But neither of these metaphors is central or indispensable for an analysis of the Christian faith experience. ${ }^{39}$ In fact, Paul's preferred metaphor is God's eschatological transformation of the human being as part of the transformation of the world as a whole. ${ }^{40}$

If we take the eschatological metaphor as the basis of his teaching we see that, apart from some apologetic inconsistencies and a dubious exegesis of the Old Testament, his theology is neither confused nor ambiguous, as often alleged, but fairly straightforward. ${ }^{41}$

\section{The struggle between flesh and Spirit ${ }^{42}$}

Paul's theology is, predominantly, eschatological theology. Protology and eschatology are both expressions of what ought to be, God's original and ultimate intentions. Therefore what ought to be tends to be couched in mythological language. Protology looks back to an

35. Freed 1994:2ff. Even the letter to the Romans, which spells out the insights he had gained previously in a systematic form, was written with a practical purpose. It was sent to Rome to introduce himself to the Roman congregation through which he wanted to extend his missionary field to Spain (15:23-29). However, to me it seems most likely that he utilised a treatise written for his existing congregations to fall back on during his long absence, provided it with an introduction (1:1-15) and a conclusion (15:14ff) and sent it to Rome. The body systematises and extends motifs which appear, for instance, in Gal and 1 Cor. The style in the additions is characterised by the humility of a guest while the body is characterised by the boldness of a leader. If true, this means that one cannot make deductions from the letter concerning the situation of the Christian community in Rome whom he did not know. An alternative view is found in Roloff: Paul wanted to make certain that the conflicts between Jewish and Gentile Christians in Rome would not jeopardise his plans (1995:131).

36. The centrality of justification for Paul's theology has been challenged since Albert Schweitzer. See e.g. Hafemann 1995:8. Sanders 1991:74: "the deeper levels of Paul's thought” are not found in the judicial categories, but in "those which express the participation of the faithful in Christ or in the Spirit, a participation which produces a real change.” Exactly!

37. Paul's stance on justification is rooted in his conflict with the Jewish doctrine of salvation (Kümmel 1972:174; cf Watson 1983:210).

38. For the latter see Theissen 1999:141.

39. The dogma of justification by grace accepted in faith, and not by achievement can be explained perfectly well, if not better, in non-legal terms with a narrative, such as the parable of the prodigal son(s). In fact the father of the boy waved his legal rights, suffering the guilt and condition of his son, for the sake of fellowship. The festival takes the place of judgment, repentance, forgiveness, reconciliation, restitution, and reintegration.

40. Cf Thielman 1989.

41. For an overview of the debate see Kruse 1996; Hafemann 1995:1-12, Breytenbach 1989:5-40, 193ff; Reventlow 1971.

42. For some of the debate see Frey 1999. 
assumed original point of departure, eschatology looks forward to the assumed ultimate goal of God.

Paul sometimes quotes, or alludes to, protological statements, ${ }^{43}$ but the structure of his argument is overwhelmingly geared to the transformation of the sinful present into the eschatological future. Therefore his operative point of departure is the death of Christ (signifying the end of unauthentic reality) and the resurrection of Christ (signifying entry into authentic reality). Salvation happens when we identify with Christ's death and resurrection through faith and undergo a provisional transformation in the power of the Spirit in anticipation of our own death and resurrection. That is the gist of the matter. ${ }^{44}$ Let us spell it out.

Paul uses an apocalyptic framework which calls sinful reality (= what is) "this age", and redeemed reality (= what ought to be) "the age to come". "Human existence in this age is called being in "the flesh" and living "according to the flesh"; human existence in the age to come is called being in "the Spirit" and living "according to the Spirit". Therefore Paul's usage of the terms "flesh" and "Spirit" should not be confused with the Greek dualism between spirit and matter. "Flesh" for Paul is the unauthentic version of the whole human being, body and soul, which is located in an unauthentic world. "Spirit" is the authentic human being, body and soul, who is involved in God's creative authority, redemptive love and comprehensive vision and who belongs to the world to come. ${ }^{46}$

In line with Old Testament thinking, the wages of sin is death (Rom 6:23). In as far as one is in the flesh or walks according to the flesh, one does not fulfil the demands of the law, and so one is condemned by the law and the result is death. In as far as one is in the Spirit or walks according to the Spirit, one fulfils the demands of the law and is saved. The result is life. This means that sinful existence will come to an end. On the cross it has come to the most horrific end imaginable, displaying the utter futility of human initiatives and achievements. ${ }^{47}$ Paul's renunciation of all his benefits (Phil 3:7ff; 1 Cor 1:18-25; 2:1ff) is rooted in this understanding of the cross. If we are to have a future at all, God must grant us a new and righteous existence. In Christ God opened up the way for both the death of the old and the resurrection into a new life to happen.

According to Paul, Christ is the "Son of God", a title given in the Ancient Near East to the king as representative and plenipotentiary of God. ${ }^{48}$ In response to the failures of the Israelite and Judaic kings, the prophets announced the arrival of a true king, a prince of

43. Phil 2:6ff is a hymn quoted by Paul. 1 Cor 8:6 also seems to be a quotation. Paul often says that God sent his Son into the world ( $\mathrm{Gal} 4: 4)$, or that Christ, the sinless, became sin, or that he was sent into the realm of sin (Rom 8:3; 2 Cor 2:21), or that he was rich and became poor (2 Cor 8:9f), but none of this necessarily implies pre-existence (vs Kümmel 1972:143; 147). Adam, the originator of sin (Rom 5:12ff), did also not pre-exist, nor did David, the father of Jesus according to the flesh (Rom 1:3f). According to the latter text, also a quotation, the status of a Son of God was established at the resurrection, but according to the tradition the "Son of David" was already a designated "Son of God" (Psalm 2). Pre-existence is claimed for Christ exp-licitly in the (deutero-pauline) letter to the Colossians (1:15ff). For the whole problem see Kümmel 1972:151ff; Goppelt 1976:399ff.

44. It is surprising how few exegetes discern that the anticipation of the eschatological transformation in faith is the basis of Paul's soteriology. Instead they get hooked by traditional legal metaphors: justification, reconciliation, expiation, restitution etc.

45. A short characterisation of Paul's use of the apocalyptic framework is found in Goppelt 1976:373f.

46. Therefore Paul can say that the risen Lord is the Spirit and that our resurrected existence will be that of a spiritual body.

47. Goppelt 1976:419.

48. In my view it is not appropriate to interpret this title on the basis of Hellenistic traditions as the Bultmann school has done. For the problem see Goppelt 1976:395ff. 
peace (Is 9; 11; Dan 7), who would redeem Israel and provide justice for the whole world. ${ }^{49}$ Paul refers to this messianic tradition when he speaks about Christ. ${ }^{50}$ In Paul's theology Christ is not God. ${ }^{51}$ Christ is the authentic human being, a creature whose intentions and potentials merges completely with those of the Creator and thus acts as a channel or instrument of the creative and redemptive action of God. ${ }^{52}$ In other words, Christ is the human being who is in faith, understood as faithfulness, ${ }^{53}$ which again is understood to be the essence of righteousness. It is in his faith, thus in his righteousness, that we participate when we identify with him through faith. ${ }^{54}$

Christ, who hailed from God and was without sin, entered the sphere of the flesh for our sakes, "became sin for us," and died on the cross. This is how the flesh was paradigmatically condemned and destroyed, thus how sin was atoned for. God raised Christ paradigmatically from the dead into a new righteous existence, the new life of Christ. ${ }^{55}$

This is how righteousness was made possible. I said "paradigmatically" because Paul juxtaposes the paradigma of Adam, in whom we are all sinners, with the paradigma of Christ in whom we are made righteous (Rom 5:19). Christ "was handed over to death for our sins and rose for us to be righteoused" (Rom 4:25). ${ }^{56}$

Because it is the authentic human being who suffered death and not a sinner, the death of Christ was a sacrificial act. ${ }^{57}$ But one must be careful not to misunderstand the statement that "he died for us". ${ }^{58}$ It does not mean that we no longer have to die. Nor does the fact

49. For detail see Nürnberger 1992.

50. For detail see Wright 1991.

51. This is clear from passages such as 1 Cor 3:23; 11:3; 1 Cor 15:20-24), from the fact that Paul never calls Christ God, that he rather calls him the "image of God" (2 Cor 4:4), as opposed to Adam who had forfeited this quality (Rom 5:12ff; 1 Cor 15:22) (cf Kümmel 1972:145f; Sanders 1991:78ff; Freed 1994:112f.). The same can be said of the letter to the Hebrews. It also agrees with the Jewish tradition of the "Son of Man", who according to Daniel 7:13 came from God but was not God (in fact, the Son of Man is later identified with the people of God verse 27). This consideration is important, because if Christ was God and not the authentic human being, we would not be able to participate in his new life.

52. Christ was the Son "because his activity was essentially united with that of God and could, therefore, depict the essence of God". Goppelt 1976:405.

53. Freed 1994:88f. Freed draws attention to the fact that the faith or faithfulness of Abraham in Rom 4:16 corresponds with the faith or faithfulness of Jesus in Rom 3:26). Faithfulness is a more appropriate concept in this regard than obedience (vs Kümmel 1972:144).

54. Freed 1994:93: the faith of Jesus (not in Jesus) is a parallel to the faith of Abraham.

55. The cross already begins with his birth (Gal 4:4). He who had no sin, Paul says, was made sin for us so that in him we might become the righteousness of God (2 Cor 2:21). Christ carries the curse of the law for us (Gal $3: 13)$. Though he was rich he became poor for our sakes so that through his poverty we might become rich ( 2 Cor 8:9). The cost is great because the authentic human being is exposed to, and becomes part of, humanity in its profound ambiguity and vulnerability.

56. The idea that the sacrificial death of Jesus atoned for sin and that this sacrificial death was "extended' by resurrection (Theissen 1999:147-150) misses the point. Without the resurrection of Christ, his death would be of no avail and believers would still be in their sins (1 Cor 15:17). 2 Cor 5:15 also signifies the identification of believers with the death and resurrection of Christ.

57. Theissen sees the sacrifice of Jesus as an act of expiation, which is "the vicarious suffering of God's wrath at all sinners which God has previously sworn" so that "God's sentence of annihilation has been passed on the crucified Jesus" and that such a sacrifice does not necessarily include the resurrection (1999:146). In Rom 3:25 and some other texts such an interpretation may be possible. But if so, it is the echo of the Jewish tradition which makes itself felt here, rather than an expression of Paul's basic theology, which cannot possibly ignore the resurrection. For him the death of Jesus is entirely useless without the resurrection (1 Cor 15:12-19)

58. The traditional idea that Paul believes in the expiatory death of Jesus, in our times defended by Stuhlmacher, is hardly tenable (Räisänen 1995:183). This does not exclude the fact that Paul, as other NT authors, makes use of traditional perceptions to bring across their message, especially in the promise-fulfilment frame of reference. 
that he became a curse for us mean that our life in the flesh is no longer under the curse. On the contrary, it means that by identifying with the death of Christ, and with his resurrection into authentic life, we anticipate our own death and our own resurrection (Rom 6:1ff). ${ }^{59}$ The phrase "for us" therefore refers to facilitation, not substitution, or expiation as commonly believed. ${ }^{60}$

Therefore it is also wrong to think that the death of Christ as such atoned for our sins, as if he was a substitute for a sacrificial animal, because that would imply the final death of Christ. $^{61}$

According to Paul the death of Christ would be entirely useless without his resurrection; believers would still be in their sin (1 Cor 15:12-19). ${ }^{62}$ What rather happens is that, as Christ died to sin and lives to God, believers consider themselves dead to sin and alive to God in Christ Jesus (Rom 6:10f; 2 Cor 5:15). ${ }^{63}$

This identification is expressed in open confession (Rom 10:9f), symbolised in public rituals, baptism (Rom 6:1ff) and holy communion (1 Cor 11:23-26), linked to faith in the resurrection of Christ (Rom 10:9) and trust in God's new way of salvation (Rom 10:11). By the power of the Holy Spirit this identification with Christ and this anticipation of our own death and resurrection develops a transformative power already in this life (Rom 6:9ff). We are transformed into the image of Christ (2 Cor 3:18), who is the image of God (2 Cor 4:4).

In as far as that is the case, they are "righteoused" by the Spirit on account of their faith, that is, their identification with, and participation in the new life of Christ. They are no longer living according to the flesh, they are no longer in sin, they are no longer subject to the law, because in Christ the demand of the law is fulfilled by the Spirit which has taken over from the flesh. It is in this sense that the law has come to an end in Christ. But all this is only true as far as and as long as we are in faith. ${ }^{64}$

The righteousness of Christ in which believers share is, therefore, an act of creation, or rather an act of eschatological reconstruction. ${ }^{65}$ This idea goes at least as far back as Deutero-Isaiah (Is 43:18f; 45:23-26; 46:12f; cf 61:3, 11; 62:1f). Related ideas are found in Jubilees $1: 23 ; 4: 26 ; 5: 12$. Therefore "in Christ" believers are a "new creation" (2 Cor 5:17; Gal 6:15). As a creative act of God, this transformation is an expression of God's redemptive will. Therefore it is not contingent upon human condition or behaviour. In Christ it has been shown that God's redemptive will is unconditional.

59. For the formula "with Christ" see Kümmel 1972:189ff and 193ff and Goppelt 1976:426ff. But that "in the eyes of God" Christ's death stands for the death of all humans (Goppelt 430) cannot be taken to be an objective reality, because then nobody would die any more. Anticipatory identification makes the formula entirely plausible.

60. Goppelt 1976:420ff is a good example for this common belief. Over against that Kümmel 183: “... von einer Genugtung Christi Gott gegenüber oder gar von der Notwendigkeit des sühnenden Todes Christi für Gottes Versöhnung ... ist bei Paulus auch nicht andeutungsweise die Rede. It is a parallel to the phrases "in Christ", "in the Spirit", "Christ in us", etc. Cf Kümmel 1972:185-189.

61. Breytenbach 1989:196f summarises the German debate. Sanders 1991:75: The sacrificial view of the death of Christ is not Paul's most characteristic view, rather "it provides the believer with a way of escape from the old creation by sharing Christ's death."

62. Cf Kümmel 1972:177: "According to Paul it is God himself who acts in the death of Christ, and God could not very well bring himself a sacrifice." Moreover, the death of Christ was not final, which one would have to presuppose for a sacrificial death.

63. When Theissen believes that the "primitive Christian sign language" is a "functional equivalent of the traditional sacrifices" (1999:156ff), he seems to overlook the fact that in Christianity traditional paradigms have been inverted. The use of traditional metaphors has the function of reinterpreting the tradition and thereby abolishing it.

64. Kümmel 181.

65. Kümmel 1972:176. 
The identification with Christ has to be realised in a continuous existential struggle "to walk not according to the flesh, but according to the Spirit". Baptism and Holy Communion are no guarantees of salvation (1 Co 10:1ff). The transfer, or transformation, from the one to the other is a constant battle between flesh and Spirit, a battle that Paul does not claim to have won as yet (Phil 3:8-14; Rom 7). ${ }^{66}$

\section{The eschatological nature of salvation}

That righteousness is a gift of God in Christ, and not a human achievement based on the resources of the flesh and this world, becomes apparent through its eschatological nature. According to Paul being righteoused happens in anticipation. The final outcome of the last judgment is still outstanding. "If the Spirit of him who raised Jesus from the dead dwells in you, he who raised Jesus from the dead will give life also to your mortal bodies by virtue of his Spirit dwelling in you ... for if you live according to the flesh, you will die; but if by the Spirit you put to death the deeds of the body, you will live" (Rom 8:11-13; elaborated in Rom 6:1-23).

The new life in which we participate is not ours, but Christ's. This side of the grave believers remain "in the flesh", are vulnerable to the powers ruling this age, have to struggle against the lures of the sin, are condemned by the law and will undergo death. Faith anticipates the death of the sinful flesh and resurrection into the new eschatological life. ${ }^{67}$ Death has to eradicate the old sinful life; God's grace has to raise the dead into the new life on account of their identification with Christ.

However, this anticipation is effective here and now. In the first place, the deficiencies in well being which we experience now are part of the process of dying to the flesh, of getting from this age to the age to come (2 Cor 4:7-18). These afflictions are not commensurate with the glory, which is to be revealed in us and through us (Rom 8:18). And in truly apocalyptic terms, this anticipation is comprehensive enough to encompass the natural world (Rom 8:19-25).

In the second place it is a transformative power. Identification with the death and resurrection of Christ happens in faith and is symbolised in baptism and Holy Communion, but if it does not lead to a transformation of concrete life, it has no substance and will carry no weight in the last judgment (1 Cor 10:1ff). Sinners will not inherit the kingdom of God (1 Cor 6:9f; Gal 5:21) and, in line with the Deuteronomic demand, Paul wants believers to disassociate themselves from the unscrupulous (1 Cor 5:9-13).

This does not mean, however, that there can be only one repentance and that we are doomed if we fall into sin again after having been forgiven. This idea, found in Hebrews 6:4-6 and 10:26-29, is foreign to Pauline theology. ${ }^{68}$ Righteousness can never become a

66. The Reformation was correct when it insisted that a believer is simul iustus et peccator (at the same time righteous and a sinner). However, this phrase indicates the constant struggle to be transformed from the one to the other, not an ontological condition or forensic status. Sanders 1991:48f believes that this phrase is foreign to Paul; it is not!

67. Luther was correct when he called the righteousness of the believer an iustitia aliena (foreign righteousness). However, this is not an error of judgment by God, as the idea of "forensic justification" might suggest, but an effective transformation of the believer into the image of Christ (2 Cor 3:18).

68. Against Freed (1994:154). Freed is forced to argue from the silence of Paul (1994:163); he also believes that "becoming members of the renewed covenant community of God did not happen on a moment's impulse but involved a somewhat lengthy process, as it did to become full members of the community at Qumran." He also presumes that "there came a time when converts ... were expected to become mature ... and to reach a point beyond which there was no return to the hope for ultimate salvation..." Such an idea is totally incompatible with Paul's soteriological approach, which is not based on being trained to lead a righteous life by 
possession of the believers; it is a gift of grace imparted by the Spirit. ${ }^{69}$ But the Spirit involves the action of the human agent. So it remains a constant struggle to leave the flesh behind and gain the new life of Christ. "Work out your salvation with fear and trembling, because it is God who works in you both to will and to succeed" (Phil 2:12f). Paul himself does not believe that he has attained it yet, but pursues it with all his might (Phil 3:13f).

\section{The Christian community}

The mortification of the flesh is by no means a lonely struggle on the strength of one's own moral potential, which could only be the potential of the flesh. It is by the power of the Spirit, whom Paul identifies with the risen Lord (2 Cor 3:17; Gal cf Gal 4:6), that believers are enabled to participate in the new life of the risen Christ already now. This new life is a communal life, because the Spirit of Christ is active in the Body of Christ, the community of those who have identified with Christ in baptism and celebrate their unity in Holy Communion (1 Cor 10:16-18).

It is important to note that, for Paul, you can have no "vertical" relationship to Christ, as opposed to, or in addition to, a "horizontal" relationship to fellow believers. "70 "The Lord is the Spirit" (2 Cor 3:17f; cf 1 Cor 15:45) or more complete, the risen Christ is the Spirit of Christ (Gal 4:6; Rom 8:9) at work in the Body of Christ (1 Cor 12:4ff; 12ff). Being "in the Spirit" is identical with being "in Christ", which is identical with being a member of the "Body of Christ". Paul can simply call the new community "the Christ" (1 Cor 12:12). Baptism signifies, therefore, at the same time, the gift of the Spirit, participation in the new life of the risen Christ, and the integration of the believer into the Christian community. These are all facets of the same process.

Though both are rites which establish identity, baptism is not a parallel to circumcision. ${ }^{71}$ Circumcision confirms that an infant, who is a descendent of Abraham, belongs to Israel, the covenant people of God. It is a rite of passage. Once circumcised, a man is obliged to keep the covenant law. Baptism symbolises the integration of a believer into a new eschatological reality which finds provisional but concrete expression in the community of believers. The Spirit replaces the law as the boundary mark of the new community. ${ }^{72}$ Not a social institution based on covenant and law, but the communal anticipation of death and resurrection establishes Christian identity. The juxtaposition between circumcision and non-circumcision is irrelevant for the Christian faith; what counts is a new creation (Gal 5:6). ${ }^{73}$

mobilising our moral resources, but on the transformation of our lives through death and resurrection which we anticipate by identifying with the death and resurrection of Christ.

69. Luther called it the iustitia aliena.

70. Christiansen is less than clear on this point: "Paul sees baptism in an ecclesiological context even when it marks identification with Christ" (1995:315). No, identification with Christ is identical with incorporation into the Body of Christ and receiving the Spirit of Christ.

71. For the relationship see Christiansen 1995:272ff.

72. Christiansen 1995:289.

73. Sanders 1991:60 finds it surprising that according to Paul circumcision is irrelevant. To me this indicates that Sanders misses the entire point. 


\section{The will of God has not come to an end in Christ ${ }^{74}$}

The basic rationale of the law is to express what ought to be, thus the criterion of the acceptability of what is. It is an expression of the creative and redemptive will of God. As such Paul takes the law to be holy and salutary. However, Paul makes a difference between living according to the concrete stipulations of the law, on the one hand, and being in line with God's redemptive intentions on the other. The former is the "letter" engraved in stone, the latter is sharing in the new life of Christ in the power of the Spirit (2 Cor 3:3, 6ff; Gal $5: 25)^{75}$

Paul thus offers his own summary of the law. The basic demand of the law is to live and act in God's power and love. The concrete stipulations of the torah are largely replaced by exhortations which reflect this basic demand. They are reminiscent of Wisdom literature (Rom 12:1ff; 13:8ff). ${ }^{76}$

As mentioned above, the transformation of the human being is a creative act of God. $\mathrm{He}$ brings about an authentic human being, Jesus Christ, in whose authenticity we are empowered to participate. This is how Jeremiah's vision of a new covenant and Ezechiel's vision of a new heart materialises. This is how the law is fulfilled, and therefore rendered redundant. We no longer meticulously observe a static set of casuistic rules and regulations to satisfy divine conditions of acceptance, but our intentions are integrated into the dynamic and redeeming intentions of God.

If the law is meant to define the kind of relationships, attitudes and behaviour which make comprehensive well-being possible, Paul does not believe that it has come to an end in Christ. On the contrary, it has been fulfilled in Christ and it is being fulfilled in us through faith, that is, in as far as we are "in Christ", or "in the Spirit", or "living not according to the flesh but according to the Spirit". He vigorously denies that being justified by grace could imply a license to sin; once you are in Christ you have died to the flesh, thus to sin (Rom 6; Gal 5:13-16).

In his exhortations Paul spells out what this pattern of relationships, attitudes and behaviour entails in concrete terms (e.g. Rom 12:1ff). He also defines the inner rationale of these formulations, which is self-giving love (Rom 13:8; Gal 5:14). He does not oppose "works" which flow out of the new motivation manifest in Christ. On the contrary, he is immensely upset when the faith of his congregations does not manifest itself in their behaviour (e.g. 1 Cor 5; 11:17ff; Gal 6:7ff). He also denies that the freedom of a believer in Christ implies that Christians can do what they like, even if it is to the detriment of their fellow believers or fellow human beings (1 Cor 8; 10:23ff). In all these matters Paul remains solidly in the tradition of Israelite-Jewish theology.

But the law has to be seen in its relation to this age and the age to come, the flesh and the Spirit. In the realm of the flesh, the law demands the new life in fellowship with God, but does not grant it. Paul clearly distinguishes between the old covenant written in letters on tablets of stone, and the new covenant written by the Spirit on human hearts (2 Cor $3: 3,6$ ). The law cannot redeem (Rom 8:3); it only gives an indication of what righteousness

74. In what follows I am in dialogue with Sanders 1991 who tries - rather unsuccessfully I think - to unravel the inconsistencies concerning Paul's stance towards the law.

75. Sanders gives a good impression of the Judaism of that time: "The greatness of the law, in Jewish eyes, lay in part in the very fact that it covers all the trivia of life and of the creation. Josephus also thought that Moses had been correct in leaving 'nothing, however insignificant, to the discretion and caprice of the individual' (Apion 2.173) ... Here life is seen as a seamless whole." 1992:248ff. This is the "totalitarian" version of the law which Paul (and Jesus before him) left behind.

76. Theissen maintains that in Judaism wisdom was owned by the upper classes, while workers were not deemed free enough to engage in it, while Jesus and Paul brought wisdom to the lower classes (1999:101ff). 
means, but it cannot bring it about. With the dawn of the new age it has become obsolete; it has been superseded by participation in the new life of the risen Christ in the power of the Spirit.

This is where Paul differs from his original Jewish position, not in the fact that we are saved by grace through faith. ${ }^{77}$ It can be argued that the law had never been a way of salvation in Judaism either, ${ }^{78}$ that Jews never tried to gain salvation through achievement, or that salvation never did not depend on God's mercy and forgiveness. ${ }^{79}$ It is clear, however, that in Judaism one could not remain in the realm of God's grace, thus lead an authentic, meaningful and prosperous life, if one did not at least attempt to live according to the law. ${ }^{80}$

Paul, in contrast, does insist that we are justified (righteous) not by the works of the law, but by the faith of Christ in God, in which we participate through the power of the Spirit. ${ }^{81}$

Paul is here in line with Jeremiah and Ezechiel who speak of the necessity for a new covenant and a new heart because the old covenant has failed due to the heart of stone. But in contrast to the Jewish tradition, he claims that the transformation promised by these prophets materialises in us already now and here as far as we live in Christ, or in the Spirit. $^{82}$

Divine righteousness now consisted in God catering for the human side of the relationship as much as his own. Human righteousness became, once again, the consequence rather than the condition of divine grace.

Paul's scheme is an exercise in transcendence: our limited moral and physical resources are transcended towards the unlimited resources God can mobilise in us and through us. This also means that the initiative of the Spirit does not exclude human initiatives but arouses and empowers them. Therefore Paul's admonitions are not out of place. But it is misleading to call the work of God's Spirit in us the "law". The good tree, which will bring

77. Sanders 1992:275f shows that Judaism too is a religion of grace!

78. "Hier kann der Jude sich nur an den Kopf greifen und wortlos staunen - denn für das Rabbinat war ja die Torah nie und nimmer ein Heilsweg zu Gott. Die Torah ist überhaupt kein Heilsweg, weil das Judentum einen solchen überhaupt nicht kennt." (Lapide 1993:31). However, it is certainly an understatement to say that, for the Jew, the law is only a way of life, not a way of salvation.

79. As Limbeck and Sanders point out. See also Hafemann 1995:9.

80. Limbeck 1972:60. Dunn 1990 shows that Paul did not simply shift to another religion but critiques precisely the Judaism characterised by Sanders.

81. In recent literature the difference between Judaism and Paul concerning the law has been played down. Räisänen believes that the "break with Judaism became logically inevitable at the very moment when the claim was raised that faith in Jesus is the only way to salvation” (125f). Sanders 1991:38 says that Paul argues backward deductively from the necessity to believe in Christ to universal sin. But why should faith in Jesus dismantle faith in the torah if there was no real difference? Some Jewish Christians remained faithful and zealous adherents of the torah. Why had Jesus been crucified? Did he really claim to be the Messiah, or did he simply interpret the God of Israel in a way different from the law - and was, therefore, taken to be the Messiah? If he had been a faithful proponent of the law, why did he get into trouble with the Pharisees? Why did Paul break with the torah-religiosity? Why did he not build on the covenant idea, but on a new dispensation? The first Christians did not break with Judaism, enter into all this conflict, subject themselves to persecution just to satisfy a logical implication of messianism. Participation in the new life of the risen Christ was an overwhelming experiential reality which problematised the old way of serving God. The saying of Jesus that the human being was not made for the Sabbath but the Sabbath for the human being is fundamental. The question is whether faith enslaves or liberates. It can only liberate if it is able to motivate in spite of failure: participation in the new life of Christ through identification offers such a way of distinguishing between our own failing resources and the resources to which we have access in faith. Dunn's (1990) clarifications are helpful in this regard.

82. Dunn 1990:162: The Antioch incident probably convinced Paul that "justification through faith" and "covenantal nomism" are not complementary emphases, but in direct antithesis to each other. 
good fruit, is not our own life, but the new life of Christ, which God has prepared for us to share, in spite of the fact that we are still sinners in the flesh.

Over against the active involvement of the believer in God's own redemptive action by the power of the Spirit, the righteousness one is able to attain by falling back on ethnicreligious privileges, or by doing the works of the law, can only be considered to be one's "own righteousness" (Rom 10:3; Phil 3:9), a righteousness reached through mobilising one's own birth right, tradition and moral resources. ${ }^{83}$

Paul does not dismiss this kind of righteousness altogether. He testifies that the lawabiders pursue "a law of righteousness" (Rom 9:31) and are "zealous for God" (Rom 10:2). Nor does he seem to believe that it is humanly impossible, in principle, to attain righteousness through the law provided one could keep the entire law (Rom 2:6f; 2:12f; 2:26f; 10:5). In fact, he considers himself blameless in terms of the law (Phil 3:6). This is an important aspect of his dialectic because it shows that the human being is not beyond redemption; there is a dormant potential to become righteous which is activated through Christ by the Spirit.

However, both religious privileges and works of the law build on the resources of the "flesh", not on those of the "Spirit". And in the flesh, that is in the sphere of humanity this side of the grave, God's vision of true righteousness does not materialise. Flesh and blood cannot inherit the kingdom of God (1 Cor 15:50). The mind geared to the flesh is hostile to God and does not submit to God's law (Rom 8:7). In the flesh one is not able to pull Christ (= authentic human existence) down from heaven, nor raise Christ from the dead; authentic existence is a gift poured into one's heart and mouth through the proclamation of the gospel (Rom 10:6-11).

It is because of this stark contrast between "our own righteousness" and the righteousness that is granted by God through faith in Christ, therefore, that Paul considers every human being, who is still in the flesh, to be a sinner (Rom 3:23) and liable to death. And it is for this reason that he considers religious privileges and even the highest moral achievement to be rubbish (Phil 3:7ff). What matters is that one dies with Christ to the flesh, so as to live with Christ in the Spirit (Phil 3:10f; Rom 6:5-11).

The law, though of God and holy (Rom 7:12f), functions in the realm of the flesh where, paradoxically, it does not only arouse the consciousness of sin but actually prompts sin, brings a curse over those who rely on observing the law (Gal 3:10) and leads to death (Rom 7:7ff). It cannot redeem (Rom 8:3), and was not meant to redeem, but to imprison (Gal 3:23f; 4:1-7), thus acting in much the same way as the worldly powers (Gal 4:8ff). ${ }^{84}$ So one can say that by dying to the flesh one also dies to the law (Gal 2:19; Rom 7:4) ${ }^{85}$ If followed by resurrection, death leads to freedom, not only from sin, thus from the curse of the law (Gal 3:13), but also from the law itself (Rom 7:6; Gal 4:5).

83. Räisänen observes that four of the advantages listed in Phil 3:9 refer not to moral achievements but to ethnicrelious privileges gained by birth and upbringing; they were, thus allotted "by grace alone". The point is, however, that for Paul birth right privileges as well as moral achievements all belong to the realm of the flesh. "Grace" does not simply refer to a divine gift, but to eschatological recreation.

84. Kümmel 1972:166.

85. Kümmel 1972:169. 


\section{The bottom line: the freedom of the sons and daughters of God}

I concede that Paul's terminology concerning the law is confusing. I believe this to be the result of his conflict with his Jewish Christian adversaries. Stung by the critique of Jewish Christians that his gospel of freedom leads to moral licentiousness, which in turn seems to have been borne out by the licentiousness of some of his gentile converts (1 Cor 6:12ff; 10:23), Paul casts his argument, especially in Romans, into heavy, legalistically sounding terminology. ${ }^{86}$

Here he is adamant that the righteousness required by the law is non-negotiable (Rom $3: 31$ ); it is the just requirements of the law which are fulfilled through faith in Christ (Rom 8:3f); Christ himself is obedient (Rom 5:19); those who are linked to Christ through faith, symbolised in baptism, cannot possibly allow themselves to indulge in sin (Rom 6:1ff); faith in Christ itself is described as obedience (Rom 1:5; 6:16; 16:19, cf 2 Cor 9:13, 10:6); Christians submit to the "law of the Spirit" (Rom 7:25; 8:2), or "God's law", or the "law of Christ" (1 Cor 9:21; Gal 6:2); believers become "slaves of righteousness" (Rom 6:18) or "slaves of God" (Rom 6:22). All this sounds legalistic and oppressive. ${ }^{87}$

Yet the thrust of his argument is the freedom of the children of God. There is a difference between observing the law and living in the power of the Spirit, or "faith working through love" (Gal 5:6) ${ }^{88}$ The intention, possibly even the outcome, may seem to be similar, namely righteousness. However, Paul speaks of a righteousness which is the "fruit of the Spirit" (Gal 5:22). Having been slaves, whether of sin, worldly powers, or the law, believers in Christ are liberated to become mature sons and daughters of God (Gal $3: 23$ - 4:11).

As mentioned above, "Son of God" is a royal title in the Ancient Near Eastern tradition, which designates the representative and plenipotentiary of God on earth. ${ }^{89}$ In one of his most heart rending appeals to his congregations Paul exclaims: "For freedom Christ has set us free; stand firm, therefore, and do not submit again to a yoke of slavery" (Gal 5:1). Slaves take orders, persons come of age are endowed with the freedom to take their decisions, the responsibility to account for them and to face their consequences. That is the heart of the matter. ${ }^{90}$

86. Theissen believes that Paul put the torah more fundamentally in question because Jewish Christians referred to it (1999:167). I see the opposite happening, namely that Jewish Christian pressure made him modify his originally much more radical stance. Roloff 1995:131 believes that there were heavy conflicts between Jewish and Gentile Christians in Rome and Paul treaded so carefully because he did not want these conflicts to disrupt his collection for Jerusalem, his planned visit and his missionary venture into Spain.

87. For the debate see Räisänen 1995:48ff.

88. After a thorough analysis, Räisänen comes to the conclusion that the use of nomos in the formulation "law of faith" or the "law of the Spirit" does not refer to the torah, but simply constitutes a polemical allusion to the latter. "Paul means God's saving act in Christ when he speaks of the 'saving order' of faith or of the spirit" (1995:68).

89. For detail see Nürnberger 1992.

90. Since Sanders' ground breaking description of Jewish piety (in fact, much earlier by Limbeck 1972:40ff and others), the curious idea came up that there is no real difference between Paul and his Jewish opponents concerning law and grace.

- On the one hand, it is argued, Jews have always believed that the law is grounded in the election and the covenant, thus in prevenient grace. Never have they tried to earn salvation by works; they have always understood that we depend on God's forgiveness. On the other hand, it is maintained, Paul is as insistent on the righteousness required by the law as any strict Jew could be, and his description of righteousness is identical with that of the law. So his furious animosity against the law is late, situational, inconsistent and ultimately inexplicable. Probably he only cut out Jewish origin, circumcision, ritual observances and purity laws to make it easier for the Gentiles to enter the fold. In essence he recognised and juxtaposed two ways of life: one based on the covenant, the other on Christ. At present James Dunn may be the 
In spite of all his warning against licentiousness, Paul does critique the law very fundamentally.

The difference in approach can be demonstrated with a picture: In the legalistic version faith is like a train which is supposed to travel along the rails of the law. So the law is the basis of our relationship with God. Sin means that the train jumps the rails and gets stuck in the mud. The gospel of forgiveness is an emergency measure which lifts the train out of the mud and puts it back onto the rail, where it continues its journey. This would be a good description of the Jewish approach to the relation between law, sin, forgiveness and reconciliation. $^{91}$

But for Paul this picture would not be appropriate because the law is in no way the foundation of our relation to God. Faith is. The law has "come in" only later (Gal 3:17-19; Rom 5:20). In the Pauline version faith resembles not a train on rails but an eagle in the air. Humans are meant to be free sons and daughters of God. Not the gospel of forgiveness is the emergency measure but the law. Sin is that the eagle hurts itself and can no longer get air borne. So it is protected in the cage of the law until his health is restored. Not the law is the basis of our relationship with God but the life giving power of God's grace, accepted in faith.

\section{Paul's inconsistencies ${ }^{92}$}

It needs to be recognised that not only Peter, but also Paul is struggling with the implications of the break-through which his interpretation of the gospel of Christ entails. Perhaps there is nothing strange about this. The task of constructing and legitimating a new symbolic universe is immense. To become acceptable, his theology had to claim continuity with what was considered by the community as the old and proven truth and what had entrenched itself for centuries in social structures and processes. Tradition has its binding and retarding effects, especially when it exerts its power in primary group loyalty. ${ }^{93}$

strongest exponent of the continuity between Paul and Judaism. For the debate see Räisänen 1995:35ff; 45f; $112 \mathrm{ff}$.

- I believe this relativisation to be fundamentally wrong. The Paul who wrote Galatians would turn in his grave if he could hear such a view being expressed by his 20th century disciples. It is true that Paul's use of terms is inconsistent and often confusing, but if one captures the pivot of his argument, eschatological transformation, the terms fall in place. It is also true that Paul believes that the basic intention of the law is the same as faith in Christ, namely "life" derived from "righteousness", but he insists that this is an eschatological gift of God which the law cannot bring about. It is also true that Paul's concept of righteousness is informed by his Jewish background, so that his adhortations are, to a large extent, similar to, or even identical with the stipulations of the torah, but there is a fundamental difference between slavish obedience and a liberated responsibility.

- All these arguments can be accepted. However, they do not imply, as some scholars seem to believe, that the clash between Jesus and the Pharisees, and between Paul and the Jerusalemites concerning the law does not really amount to much. If they were right, there would be no fundamental difference between Jews and Christians, or between proselytes and Gentile Christians. The only difference would be that Christians linked righteousness with following Jesus, whom Jews could recognise as a good, though somewhat overzealous, Jew. In fact, the difference is fundamental, otherwise the fatality of the clash between Jesus and the Jewish leaders and between Paul and his Jewish Christian and Jewish adversaries is incomprehensible. It was really a life and death issue, not a little quibbling on what is to be included in the rules to be observed and what could be left to the individual.

91. Sanders 1992:270 shows that repentance and forgiveness were freely available in Judaism. Judaism is a religion of grace (275f): "Fundamental to Jewish piety was the view that God's grace preceded the requirement of obedience and undergirds both the life of Israel and also the entire universe."

92. Cf Räisänen 1986.

93. "Precisely the tension between a novel liberal practice (which signals an actual break with the sacred tradition or the old symbolic universe) and a verbally conservative ideology (which stresses continuity with the old) 
However, two thousand years hence we have to call a spade a spade. Being thrown into entirely new situations, there is no reason why we should perpetuate his ambiguities. "If the bugle gives an indistinct sound, who will get ready for battle?" (1 Cor 14:8). Paul falls back into the way of the law ever so often, especially in connection with Jewish privileges, the superior status of men and the right of masters over slaves. In this connection it is clear that Romans was a systematic treatise where he wanted to give account of his stance towards the Jewish tradition, while his other letters were more spontaneous, less guarded and therefore closer to his basic stance. ${ }^{94}$

In Gal 3:23-4:7, the liberation brought about by the gospel is based on identification with the crucified and risen Christ, who is the heir to the promise (26-29). Thus "there is neither Jew nor Greek, slave nor free, male nor female, for you are all one in Christ Jesus" (Gal 3:28). Alas, in the parallel 1 Cor 12:13 the difference between men and women is omitted from the formula; in Rom 10:12 slaves are also omitted. In 1 Cor 11:3ff a hierarchy is established between Christ, husband and wife with problematic arguments, and in 1 Cor 14:34 Paul expressly appeals to the law when he prohibits women to speak in the congregation. Now that is an about-turn for you!

Similarly, in Phil 3:3-11 Paul subsumes all the privileges the Jews might have had over against Gentiles to the flesh and consigns them to the rubbish heap in favour of knowing Christ, sharing his suffering and attaining resurrection. In Romans, in contrast, he is strangely apologetic concerning the privileged position of the Jews (9:4f). Let us look at some examples.

In Gal 6:15 and 2 Cor 5:17 those in Christ are a new creation ("the old has gone, the new has come"). In Romans 11:16-24, in contrast, the branches (the Jews) are holy (11:16), because the root (the promise to Abraham) is holy. Gentiles are grafted into the old tree of Judaism.

In Gal 3:23f he maintains that we were held prisoners of the law until faith came. In Romans it is not impossible to attain righteousness through works of the law and only the hypocrites, who preach to others and fail to keep the law, are condemned (2:7-25).

While in Gal 6:15 neither circumcision nor uncircumcision amounts to anything, but only a new creation; in Romans the value of circumcision, though spiritualised $(2: 28 \mathrm{f})$, is upheld (2:25f).

One may get the impression that the Letter to the Romans is at least a partial retraction of the crude but clear stance taken in Galatians and Philippians. But even in Romans Paul endeavours to affirm that Jewish privileges are illusory (Rom 3:9; 9:6ff; 9:22f; 10:4ff; 12:1). And so his stance becomes contradictory, especially in the "tortured section Romans 9-11". 95

However, this can be explained quite adequately as an attempt to legitimate the new approach in response to the intense attacks he was subjected to by representatives of the old tradition, of whom he was a part, to whom he felt a deep commitment (Rom 10:1ff) and

leads, not just Luke but even Paul into difficulty ... Legitimation, however, is not always a very conscious process ... Attributes of the old law are self-evidently applied to the new ethos that has in fact replaced the old, but the phenomenon is never admitted, let alone analysed. The new is spoken of as if it were identical with the old" (Räisänen 1995:268).

94. Romans contains 52 quotations from the OT, of those 28 in chapters 9-11. 1 Cor which is almost equal in length only has 16, 2 Cor only 9 . Gal has 10 - because again he had to argue with the tradition. Goppelt 1976:379.

95. Räisänen 1995:271; cf 30f; 188ff. 
from whom - this should never be forgotten - a threat to his life emanated. ${ }^{96}$ The motive is apologetics, not retraction, or compromise. This brings us to the next topic.

\section{Paul's indebtedness to the tradition}

It should be recognised that Paul's stance - and indeed that of Jesus - is in continuity with Old Testament and Jewish trends. But the tradition had branched out into various directions which had begun to distance themselves from each other. Due to historical reasons, the legalistic stances had acquired overpowering influence in Judaism, while their nascent alternatives had not fully matured. Certainly they never attained the rank of orthodoxy.

The conflict we find in New Testament times is prefigured, therefore, by the clash between incompatible alternatives already existent within the Judaism of the time. In the end the question was which interpretation of the God of Israel was valid, that of Jesus and Paul or that of the pharisaic-rabbinic tradition. This also means that the "new" approach Paul stands for is accessible from within the traditions of Judaism, at least in principle, though according to Paul Jews would have to accept its ultimate realisation in Christ.

Much attention has been given in recent times to the question whether Paul's conflict with law-abiding Jews has not led to a totally distorted picture of Judaism, which in turn fuelled anti-Semitism. ${ }^{97}$ After Auschwitz the task to put the record straight is of critical importance. Jews must be allowed speak for themselves, prejudices must be abandoned, an untenable Christian position must be dismantled, Christians must repent of centuries of scape-goating and persecution. Most importantly, in the gruelling conditions of the holocaust, Jews arrived at conclusions which were very similar to those of Christianity. ${ }^{98}$

However, in terms of our present programme, whether Paul, Luther, or the Pietists have done justice to the Jewish position is not really the point. The point is what Paul stood for in contrast to its (constructed or real) alternatives. Here are a few indications of his indebtedness to the tradition:

Following the Old Testament, Paul believed in the unlimited mastery of God. God is the source of experienced reality as a whole and nothing exists or happens without God's creative and redemptive activity. ${ }^{99}$ To trace God's action one simply has to read history backwards and look at what happened in reality. If Pharaoh has hardened his heart, it is God who has hardened Pharaoh's heart; if Gentiles came to believe in Christ, it is God who opened their hearts for salvation. ${ }^{100}$

God is the Creator, not a creature among others. God's action does not compete with human action, but initiates and empowers human action. His is on another level of

96. According to Räisänen this is a problem inheremt in any attempt to relate the new symbolic universe positively to the old (1995:272). However, it must also be stated that, as Galatians and Philippians show, Paul under no obligation to do that.

97. Luther is particularly guilty in this respect. He was unable to see that the gospel of justification by grace, accepted in faith, and not through achievement or status, implied unconditional acceptance of the unacceptable. His assault not only on the Roman Catholic leadership (who were in power) but on the small minority of Jews (from whom he had nothing to fear) is inexcusable.

98. For instance in the works of E Wiesel we find notions of the "hidden God" which are very similar to those of Luther, though the afflications of Luther are incomparable with those of the survivors of Ausschwitz. In her comparison of Jewish concepts of the silent, absent, malicious, abusive, exiled, suffering God with its equivalents among victims of South African forced removals, Fröchtling 2000 shows how close the existential experience between Jewish Germans and South African Blacks could become under conditions of severe oppression. It is also remarkable that Mark Chagall often depicts the crucified Christ within the Jewish context.

99. Cf Sanders 1992:249ff.

100.Cf Sanders 1991:42ff. 
causation altogether. It is worth our while to repeat Paul's most characteristic formulation in this regard: "... continue to work out your own salvation with fear and trembling, because it is God who works in you both to will and to act according to his good purpose" (Phil 2:12f). We can act because God acts - whether to our salvation or our demise.

Another text which expresses this insight is Phil 3:12f: Paul strains himself to seize salvation, after he has been seized by Christ. It is not true to say, therefore, that God does his part and expects believers to do their part. Rather, God enacts his purposes through our acts, and we act being enabled by the acts of God.

That God is the Source of the whole of reality, as experienced by us, is not a new idea. It is one of the most outstanding characteristics of the Old Testament faith. Its application to the problem of redemption is also not new. But here the record is highly ambiguous. The reason is the inherent tension between two biblical faith assumptions: God's mastery and God's benevolence. If God was in charge of reality, experienced calamities could only be ascribed to God's wrath. God's wrath could only have been caused by human sin. But who was responsible for human sin?

The implication of the covenant was that God and humans were partners, each having obligations to fulfil. If one partner reneged, the covenant was in jeopardy. Moreover, the covenant was not a voluntary association between two partners at the same level of dignity, but an imposition on the human partner by the divine master over life and death. So if Israel broke the covenant, Yahweh had to punish, even destroy it.

The inconsistency in this construction was that God and humans do indeed seem to operate at the same level. The human partners were treated as if they were free and autonomous equals of the divine partner. But this did not match with the assumption that all of reality was caused by God. Israel was blamed for its hardened heart, yet the hardening of hearts had to be ascribed to God's action.

The logic entangled itself even further: God hardened the hearts of Israel so as to have grounds for punishing, even destroying Israel (Is 6:9ff). But this was again in complete dissonance with the other assumption of the biblical faith, namely that God was intrinsically benevolent and faithful to his people.

As we have seen, some prophets had already realised that, if Israel was to be saved, God would have to transform or recreate its most innermost motivations. And because the whole of reality did not conform to God's redemptive intentions, a new humanity would have to be part of a new heaven and earth. In the end, therefore, it was more important for Yahweh to have a change of heart than for Israel, because the latter could only flow from the former. But according to Paul, God had in Christ already committed himself unconditionally to the salvation of humankind. In the end, Paul was convinced, even the hardness of heart among the Jews must be part of God's master plan (Rom 11:28-36).

Paul's argument in Rom 9-11 may seem to be tortured and far fetched but it highlights an important insight: God can utilise even our sins for his redemptive purposes. And this is a genuine Old Testament idea, which found its literary expression in the narrative of Joseph and his brothers (Gen 37ff).

The answer to the insoluble problem of theodicy could only lie in the future. In the end God would have to solve the contradiction between his mastery and his benevolence by bringing about, in his power, a reality which corresponded with his benevolence. It is this eschatological tradition that Paul took up, especially in Romans 9-11.

But he maintained that the eschatological transformation had already commenced in the death and resurrection of Christ and that, in the power of the Spirit, this eschatological transformation can be shared by those who identify with Christ. Faith in Christ, or rather 
sharing the faith of Christ, means that the will and the action of the believers are taken into the dynamics of God's redemptive will and action through the power of the Spirit. It is the Spirit of Christ which motivates and empowers them to transform themselves and their world. The freedom that Paul speaks about is achieved, not by moral looseness, nor by moral rigidity, but by participating in God's creative authority, redemptive concern and comprehensive vision for the world.

The non-believers, in contrast, remained within the obstructive sphere of the flesh. As Isaiah had already suggested, this had to be attributed to Yahweh. ${ }^{101}$

But this again did not mean that these non-believers were not to be held accountable for their attitudes and actions. Taken to logical conclusions, the alternatives at the divine level were an enslaving versus a liberating determination of the human will by God. At the human level we are called upon to take a decision for or against the new life of Christ, struggle with God against the power of the flesh and work out our salvation with fear and trembling in the power of the Spirit.

\section{Critique of the law}

Let us pause for a brief reflection on Paul's ground-breaking insight concerning law and grace. When the law becomes the basis of our relationship with God, four dysfunctions seem to follow. In the first place, the law makes acceptance into God's fellowship conditional. According to Deuteronomy 7, 28 and 30 you are blessed if you keep the law, and cursed if you transgress it. ${ }^{102}$ In spite of the prevenient grace of election and covenant, acceptance into God's fellowship depends on the fulfilment of the law. In fact, the election of Israel, and the special covenant with Israel, impose a further condition of belonging. It excludes the Gentiles - even to the extent that murder ( $\mathrm{Nu}$ 25:6ff) and genocide (Deut 7; cf Ex 23) were sanctified as appropriate human manifestations of Yahweh's zeal. In this approach in-group identity necessitates out-group exclusion.

In contrast, the gospel of Christ announces God's unconditional, suffering acceptance of the unacceptable into God's fellowship. He accepts us into his fellowship "not counting our sins" (2 Cor 5:19). Christ died for us (= God suffered us) while we were still sinners (Rom 5:6-8). All we do is to accept being accepted. Identity is established by incorporation into the community of forgiven sinners. It is an open, assimilating kind of identity. Those who are excluded have excluded themselves. Suffering is endured, not inflicted. ${ }^{103}$ The incompatibilities between ancestries, cultures, traditions, convictions, values and norms are borne for the sake of fellowship. In fact, the church of Jews and Gentiles would haven been unthinkable had the gospel not signified God's unconditional acceptance of the unacceptable.

The grace of election is, therefore, not at all the same as the grace of unconditional acceptance of the unacceptable, a fact which is often overlooked in recent literature. ${ }^{104}$

101.In traditional Christian theological terminology, Paul applies the biblical belief in God's "providence", which is normally located within the doctrine of creation, to the doctrine of salvation.

102. Sanders 1991:57 says that Dt 27:26 is the only place in the LXX which links law and curse and that Paul uses this verse to curse his opponents. Really?

103.Christiansen 1995:54, footnote 124.

104.Against Sanders and others Dunn 1990:231 sets the record straight: "That the law served to identify the Jewish people as the people chosen by the one God for himself, and as a boundary to mark them off from all (other) nations, would have been a basic assumption of Jewish self-understanding ... Jews (including Jewish Christians) would be particularly sensitive at the points where the boundaries seemed to be threatened and consequently their own identity threatened." It is this which Paul attacks as "boasting". 
As a result there is no place for discrimination in the new dispensation. Therefore, neither historical privileges nor moral excellence count (Phil 3). Jews and Gentiles will be judged according to their behaviour (Rom 2:6ff); Jews and Gentiles will be saved through their participation in the righteousness of the risen Christ (Rom 3:21ff).

In a rare moment of truth, Paul realises that God's gift of unconditional suffering acceptance of the unacceptable into God's fellowship also precludes any discrimination against women and slaves (Gal 3:26-29). Alas, he was not able to persist in this revolutionary insight with the same determination in the case of women and slaves as in the case of the acceptability of Gentiles. We shall soon return to that.

In the second place, if it forms the basis of our relationship to God, the law does not draw on the creative and transformative power of God. It formulates the criteria of righteousness for a people living in this age who do not have the resources to fulfil it. In contrast, according to the gospel of Christ God accepts the unacceptable, not to condone their unacceptability, but to transform them into sons and daughters of God. Participation in the new life of the risen Christ in the power of the Spirit is "a new creation" which belongs to the "age to come". While the requirements of the law were supposed to be met by drawing on the ethical resources of the old human being, participation in the new life of Christ is, and always remains, a gift of God. Again, the grace of election is not the same as the grace of transformation - which also tends to be overlooked in recent literature.

In the third place such a law is imposed, not worked out by liberated and mature "sons and daughters" of God who act in responsibility before God and their community. At least in some of its Old Testament versions, the law requires slavish obedience, not participation in the dynamics of God's redemptive action. When Paul speaks of obedience, he does not mean slavish adherence to fixed formulations, but the commitment to crucify the flesh, live in the Spirit (Rom 6:1-18) and bring forth fruit such as love, joy, peace, patience, kindness, and self-discipline. (Gal 5:22). Paul formulates admonitions which exemplify the kind of behaviour which is in line with God's redemptive vision, but does not have the character of a set of preformulated legal requirements. Paul asks his congregations, being "sensible people", to "judge for themselves" what the will of God might be (Rom 12:2; 1 Cor 10:15; 11:13).

In the fourth place such a law becomes an end itself and obscures its original rationale, namely God's redemptive vision for the world. As such it acts much like the "elements" which are not entitled to govern the world (Gal 4:8ff). Jesus restored this rationale when he maintained that the Sabbath was created for the human being, not the human being for the Sabbath. This saying can be extended to all other stipulations of the law.

Finally, such a law is static. The law is formulated as a set of specific stipulations, not as a living response to changing situations of need. ${ }^{105}$

A static law, formulated in antiquity, binds believers into obsolete patterns of behaviour, while it cannot cover the drastically new problems and situations we encounter in the modern world. If the law is taken to be "revealed" and valid for all times and places exactly as it is, the fact is obscured that it emerged and evolved in a historical process in response to constantly changing situations of need.

105.This can be demonstrated with a contemporary example. Although the original reason for the prohibition of the Canaanite fertility rite of boiling the meat of a kid in the milk of its mother (Ex 23:19) has long disappeared, orthodox Jews will still be careful not to mix meat dishes with milk dishes and even keep two sets of crockery and cutlery so as to make absolutely certain that the mixing does not even occur inadvertantly. Observance has taken the place of reason. The same would be true for Christian women who take Paul's injunction to cover their heads (1 Cor 11:1ff) as the eternally valid will of God. 


\section{Paul's disciples}

When it comes to formulating the relationship between law and grace, Paul is a giant towering high above other New Testament authors. Paul's treatment of the law is possibly the most complex and most significant of all the inversions of soteriological paradigms in biblical history I have observed in my research. The Deutero-Pauline letters (Col and Eph) are based on the Pauline approach, but they reveal highly significant theological shifts. We shall concentrate on the letter to the Ephesians where the changed paradigm has been fully developed.

In the first place the frame of reference is no longer time but space and authority. What ought to be is located no longer in the future (1 Cor 15:20-28), but in the "heavenly places" (en tois epouraniois) (Eph 1:20ff). For Paul what ought to be is not yet present reality, but an anticipation of what is to come, although, through the faith of the believers, this anticipation has a definite and powerful impact in this world. For Ephesians, in contrast, what ought to be is present reality, but one which still needs to be revealed, although, through the believing church, the hidden truth again has an impact in this world (3:10). In Col 3:1ff and Eph 1:20ff Christ is seated at the right hand of God and believers are already in heaven, in as far as they "have died" and their lives are "hidden with Christ in God". Because of the non-arrival of the parousia, Paul's future orientation - and that of the early church as a whole - had to change in one way or another. This is one way, the existentialist stance of John another, Luke's historical scheme yet another.

In the second place Paul's eschatological approach leads to a dynamic understanding of our participation in God's redemptive purposes. The moment it is abandoned, the Pauline school reverts back to the idea of a cosmic order. According to Paul, Christ will rule until he has subdued all powers, when he will hand over the kingdom to God (1 Cor 15:23-28). According to Ephesians Christ is enthroned at the right hand of God, above a hierarchy of powers which control this world (1:18). Under his rule the cosmos (ta panta) is to become one integrated whole $(1: 10 ; 4: 10$; cf Col 1:15ff)). Protology is emphasised: God's master plan dates back to the foundation of the world $(1: 4 ; 3: 5,9,11)$ and Christ is the pre-existent instrument of creation Col 1:15ff).

Similarly Christians are God's workmanship created in Christ for good works which God had prepared beforehand for us to do (2:10). In plain language, our lives are fitted into a structure of human attitudes and behaviour pre-established by God. The vision is clearly one of "law and order", not of freedom as in Paul (Gal 3:21-4:11).

The cosmic order has its equivalents in the ecclesial sphere. The flowering gifts of the Spirit in 1 Cor 12-14 and Rom 12 have become ecclesial offices in Eph 4:11f. By parallel sing it with the relation between Christ and the church, the patriarchal relation between husband and wife is cast into an ontological order (5:25-33). Unfortunately, Paul has provided a precedent for such arguments (1 Cor 11:3ff; 14:34ff).

In the third place Christ, the ruler over the cosmos, is also the head of his body, the church (1:20f). The metaphor changes from signifying the relation between the body and its members to that of the body and its head. It is no longer meant to be a picture for the unity and diversity found in the fellowship of believers as in 1 Corinthians 12-14, but a structured social organism. As such it is an alternative social order. The body has a particular task in this world: to make known the hidden wisdom of God to the powers which control the universe (Eph 3:10). It is a cosmic mission which can lead to severe conflicts with the powers of darkness (Eph 6:10ff).

Fourth, the church is composed of Jews and Gentiles. It was the law which had separated the two factions of humankind from each other. This "dividing wall of hostility" 
has been dismantled through the cross of Christ (2:14f). Acceptance into the fellowship of God is by grace, not by works (2:8f). Those who were near (the Jews) and those who were far (the Gentiles) are integrated into one new humanity (2:15f), which is the temple of the Spirit (2:20-22). All this is genuine Pauline theology, but Ephesians does not see a need to continue with Paul's dialectical approach to the law.

Finally, living in sin does not lead to death, but is death (Eph 2:1). Becoming a believer, and being a part of the body of Christ, is tantamount to being raised from the dead and enthroned with Christ in the heavenly places (Eph 2:5-6; cf Col 3:1-4). In these two aspects the theology of Ephesians resembles that of John's Gospel (John 3:16-18; 5:24f), except that Ephesians has a cosmic, rather than an existential frame of reference. The transition from death to life, which in Paul is anticipated through identification with the death and resurrection of Christ, has already been realised in Ephesians and Colossians and only waits to be revealed. Again we see that the Deutero-Paulines shift the emphasis from the dimension of time to the dimensions of space and power.

The Pastoral Letters betray a full-scale return to the "law" as the basis of our relationship with God. In contrast to 2 Cor 3, the Old Testament Scriptures are inspired to make us wise for salvation in teaching, rebuking, correcting and training in righteousness to equip us for every good work (2 Tim 3:14-17). That salvation comes about through faith in Christ Jesus (3:15) appears almost like an after-thought. It has become, in the mean time, an accepted and formulated dogma, but it does not represent the heartbeat of the Pastoral Letters.

The Pastoral Letters do not go back to the old Israelite dialectic between the covenant and the law. The covenant is never mentioned. Nor do they quote the torah as the final and eternal decree of God. What really counts for them is our moral seriousness and excellence. A man must cleanse himself, become holy and useful for any good work, flee youthful desires and pursue righteousness (2 Tim 2:21f). The atmosphere is much like that of some forms of post-exilic Wisdom literature.

The grace of God appeared merely to educate us to abolish ungodliness and to live righteous lives in this world, while Christ gave himself as a ransom from all wickedness and purify for himself a special people, zealous for good works (Tit 2:11-14).

It would seem that, apart from residues in the form of fixed dogmatic formulations, which can be very pithy, the Pauline gospel of God's transformative action has been lost. ${ }^{106}$ In time this trend attained dominance, so that (early) "Catholic Christianity comes close to covenantal nomism; only, the covenant is established in Jesus ..." From Justin and Irenaeus onwards "a primordial natural law consisting of ethical demands" is postulated - which boils down to a revitalisation of the cosmic order. ${ }^{107}$

As in similar cases, a law which is derived from inspiration or revelation tends to legitimate and entrench social structures. We have seen that in his motivation for female silence and submission in the congregation, Paul himself falls back on the law (1 Cor 14:34) - which he had previously declared to have been superseded by freedom in Christ (Gal 3:23-28). In the Deutero-Paulines women and slaves are admonished to subject themselves to their place in society.

All this is bad enough. But it is in 1 Timothy 2:9-15, that this trend reaches its truly incredible peak: women must submit and be silent because: (a) Adam has been created first.

\footnotetext{
106. Here at the latest we come across the limitations of Freed's interpretation of faith as nothing but faithfulness and faithfulness as nothing but righteousness. Referring to Tit 2:11-14 he says: "Paul ... would have been glad to learn that what he had written had produced such fruit of the Spirit in a later follower of his" (1994: 160). 107.Räisänen 1995:277. I am certain of nomism; I am not so certain about the covenant.
} 
What about Gen 1:27 and Gal 3:26-28? (b) Not Adam, but Eve has been deceived and became a sinner. What has become of Paul's statements that all humankind has sinned (Rom 3:23) and that it is in Adam that we all die (1 Cor 15:22)?

But wait for more: (c) Women will be saved through child-bearing - with the additional condition that these children also continue in faith, love and holiness with propriety (1 Tim 2:15). According to Paul, I had thought, we are saved through God's grace in Christ, accepted in faith? This is religious legitimation of institutionalised dominance at its worst. As we all know, this development did not stop there. In 1 Clement "obedience towards God is obedience towards Clement of Rome”, period (Räisänen 1995:222).

\section{Conclusion}

Paul's theology can be seen as the peak of an evolutionary movement. A mountain experience is difficult to maintain. It is as if the tradition climbs up to this peak and then moves down again on the other side. The decline begins in Paul's own career. When faced with the threat of lawlessness in his congregations, on the one hand, and ostracism and martyrdom at the hands of his law-abiding Jewish opponents on the other, he picked up serious qualms. Even in the Christianity of today appropriations of Paul's ground-breaking insights are few and far between. It is far easier for a train to puff along fixed rails than to make its way through jungles of freedom.

\section{Contemporary relevance}

The heart of the biblical message is, at the same time, the most pervasively relevant issue in modern times, in fact, at all times. The difference between conditional and unconditional acceptance - and the kind of conditions imposed before acceptance and belonging are granted - structures the psyche, the primary group, the economy, the body politic, the international power play. It is impossible to analyse these phenomena in detail. Let us briefly mention a few examples:

Marriage: The commitment "until death doth part us" signifies unconditional, suffering and healing acceptance between the marriage partners, in spite of all disappointments and adversities. During a long life together, unacceptability can become a severe burden and only the willingness to suffer each other can uphold trust and fellowship. And that is all important. One needs one place in the world where one is at home, where one is allowed to drop all masks and pretences, where one can be oneself and be accepted as such.

Child rearing: A stable, loving family is not a romantic dream but a social necessity. It forms the indispensable canopy under which the next generation can mature. A child can only develop into a healthy adult in the context of unconditional acceptance. Problem children, in particular, need to be accepted before they can be transformed. The lack of acceptance may actually be the cause of the problem.

Social reality: Society is structured in a great variety of groups. Most of these groups impose a system of conditions which define boundaries to keep those inside in and those outside out. This "ingroup-outgroup" phenomenon is a powerful means of social control. Outsiders are experienced and treated as strangers and potential enemies. Even the potentially dangerous impact of guests is cushioned by ingenious rules of politeness.

Close knit primary groups in particular, such as school classes, gangs, extended families, platoons, boards and cabinets can be characterised by group solidarity at all costs, a lack of individual freedom, involuntary surrender of responsibility, a lack of accountability towards the wider public, and - in severe cases - to unbelievable atrocities. 
But primary group loyalty can be extended to ethnic groups, religious affiliations, classes and nations.

The economy: In a traditional economy individuals have closely defined social roles and statuses and are acceptable only if they do not transgress their spheres of competence an arrangement which stifles initiative, ingenuity and excellence. Similar observations can be made in a feudal and a socialist economy. A liberal economy accepts everybody into the competitive game, which account for its enormous dynamic, but then imposes the achievement norm as the most ruthless condition of acceptance, belonging and status. Those who can outcompete or outsmart others rapidly rise in power and status, while those who cannot drop out of the game.

Politics: During colonialism and apartheid several generations of blacks have been traumatised, not only because whites imposed conditions of acceptance, but because these conditions where such that blacks could not possibly fulfil them. If you are black you cannot become white, how hard you try. So in fact discrimination is not just conditional acceptance, but rejection. The same is true for gender discrimination. If you are women, you cannot become a man. It is a sad irony that affirmative action, which tries to rectify injustices of the past has the same effects on those reversely discriminated against.

In a democratic society everybody is accepted unconditionally into the decision making process, but group loyalty within political parties can lead to subservience rather than critical participation and public accountability.

Those who are excluded because they cannot fulfil certain conditions lose selfconfidence, initiative and drive, become fearful, withdrawn and listless. This is a sure recipe to create a social stratum of dropouts. Alternatively these people assert themselves against society, become social misfits, delinquents, criminals or revolutionaries.

Health: An absolutely critical instance of the relevance of unconditional acceptance is the AIDS crisis. The "law" is important as the pragmatic formulation of the preconditions of healthy survival under present circumstances. A few simple rules would arrest the spread of the virus immediately: life long one-partner relationships, no pregnancy of infected mothers, no drug abuse, a life style which builds up the immune system, suitable protection of health workers.

But the law cannot redeem. Once a person is infected, the gospel of unconditional suffering acceptance must kick in to transform a doomed life during its last years. Shame, secrecy, taboos, ostracism, work place discrimination, breakdown of family ties, extreme loneliness in severe suffering are all caused by conditional acceptance and can only be healed through unconditional acceptance. The gospel can transform an infected person during his/her last days into an ambassador for the redeeming power of the gospel, and for the kind of positive, wholesome living which it can bring about.

Religion: In a pluralistic postmodern climate it is not always realised that religions differ vastly from each other in terms of the character of their normative systems. This can range from mechanical observance of rituals, through "revealed" laws which are transgressed only at the peril of one's soul, to critical responsibility. Obviously the contents of ethical precepts also differ widely.

Most important is, however, the character of the relationship between the divine and the human partner. There are religions in which the unpredictable moods, the anger, or the selfishness of deities demand asceticism, meticulously performed rituals, slavish obedience to laws, whether they make sense or not, or indeed sacrifices - often human sacrifices! All these are instances of conditional acceptance. 
It has been claimed by theologians that Christianity is, in fact, the only religion where acceptance is unconditional, so that human obedience or righteousness is not a condition but a consequence of divine acceptance. However, the truth is that most forms of Christianity enslave rather than liberate their adherents. This is the reason why the church is splintered into irreconcilable groups, each with its own conditions of fellowship and belonging.

Moreover, there is episcopal authority, canon law, the expectation that one gives one's life in a crusade, puritan legalism, confessional exclusiveness, the demand to accept the inerrancy of Scriptures, even where makes no sense, being filled with the Spirit and speak in tongues as the criterion of a true believer, observance of certain days, and a host of other things. Both Pauline theology and the Reformation were attempts to break open these "Babylonian captivities", only to fall back into their own enslavements.

The rediscovery of God's unconditional suffering acceptance of the unacceptable, which leads to the transformation of people enslaved by inner compulsions and outward pressures into mature, free and responsible sons and daughters of God is still outstanding. It is also the foundation of genuine tolerance, as opposed to indifference or self-delusion, in a pluralistic context. 


\section{BIBLIOGRAPHY}

Alt, A 1989. The origins of Israelite law. In: Essays on OT history and religion. Sheffield: JSOT Press 1989:79-132.

Boecker, HJ 1980 (1976). Law and the administration of justice in the OT and the ANE. Minneapolis: Augsburg, 1980.

Bornkamm, G 1966. Das Ende des Gesetzes. München: Chr. Kaiser, 1966.

Braulik, G 1982. 'Gesetz als Evangelium' ZThK 79, 1982-2, 127-160.

Breytenbach, C 1989. Versöhnung: Eine Studie zur paulinischen Soteriologie. Neukirchen: Neukirchener Verlag.

Brueggemann, W 1994. A social reading of the Old Testament: Prophetic approaches to Israel's communal life. Minneapolis: Fortress Press.

Christiansen, EJ 1995: The covenant in Judaism and Paul: A study of ritual boundaries and identity markers. Leiden et al: Brill.

Conzelmann, H 1968. Die Rechtfertigungslehre des Paulus: Theologie oder Anthropologie? EvTh 28, 1968, 389-404.

Crüsemann, F 1989. 'Der Pentateuch als Torah' EvTh 49, 1989-3, 250-267.

Dunn, J 1975. Rom 7, 14-25 in the theology of Paul. Theologische Zeitschrift 31/1975 257273.

Dunn, J 1990. Jesus, Paul and the law. Louisville KY: Westminster John Knox (essay 183206)

Freed, ED 1994. The apostle Paul, Christian Jew: Faithfulness and law. Lanham, New York, London: Univ Press of America.

Frey, J 1999. Die Paulinische Antithese von "Fleisch" und "Geist" und die palästinischjüdische Weisheitstradition. ZNW 90/1999, 45-77.

Fröchtling, A 2000. Exiled God and exiled peoples: memoria passionis and the perception of God during and after Apartheid and Shoa. Pietermaritzburg: University of Natal, PhD thesis.

Gerstenberger, E 1965. Wesen und Herkunft des “apodiktischen Rechts”. Neukirchen: Neukirchener.

Gese, H 1977. “Das Gesetz”. In: Zur biblischen Theologie. München: Kaiser, 55-84.

Goppelt, L 1976. Theologie des Neuen Testaments, Zweiter Teil. Göttingen: Vandenhoeck \& Ruprecht.

Hafemann, SJ 1995. Paul, Moses, and the history of Israel. Tübingen: Mohr (Siebeck).

Hengel, M 1991. The pre-Christian Paul. London: SCM/TPI.

Hübner, H 1980. Das Gesetz bei Paulus. Göttingen: Vandenhoeck \& Ruprecht 1980.

Kruse, CG 1996. Paul, the law and justification. Leicester: Apollos (Inter-Varsity).

Kümmel, WG 1972. Die Theologie des Neuen Testaments nach seinen Hauptzeugen - Jesus Paulus Johannes. Göttingen: Vandenhoeck \& Ruprecht, second edition.

L'Hour, J 1967. Die Ethik der Bundestradition im AT. Stuttgart: Katholisches Bibelwerk.

Lapide, P 1993. Paulus zwischen Damaskus und Qumran: Fehldeutungen und Übersetzungsfehler. Gütersloh: Gerd Mohn, second edition.

Larrson, E 1985. Paul: law and salvation. New Testament Studies, 31/1985, pp. 425-436.

Levenson, JD 1976. Theology of the program of restoration of Ex 40-48. Missoula Mont: Scholars Press. 
Liedke, G 1971. Gestalt und Bezeichnung alttestamentlicher Rechtssätze: eine formgeschichtlich-terminologische Studie. Neukirchen: Neukirchener.

Limbeck, M 1971. Die Ordnung des Heils. Untersuchungen zum Gesetzesverständnis des Frühjudentums. Düsseldorf: Patmos.

Limbeck, M 1972: Von der Ohnmacht des Rechts: Zur Gesetzeskritik des Neuen Testaments. Düsseldorf: Patmos. Düsseldorf: Patmos.

Limbeck, M 1997. Das Gesetz im Alten und Neuen Testament. Darmstadt: Wissenschaftliche Buchgesellschaft. 253 S DM 45.

Lindemann, A 1973. Die Gerechtigkeit aus dem Gesetz. Erwägungen zur Auslegung und zur Textgeschichte von Römer 10:5. ZNW 73, 1982-2, 231-250.

Niebuhr, K-W 1987. Gesetz und Paranäse. Katechismusartige Weisungsreihen in der frühjüdischen Literatur. Tübingen: Mohr.

Nürnberger, K 1992. The royal-imperial paradigm in the Bible and the modern demand for democracy. Journal of Theology in SA, No 81, Dec 1992, pp 16-34.

_ 1993a. The God of Abraham, Isaac and Jacob: The trajectory of a soteriological paradigm in biblical times. Scriptura 46/1993, pp 1-23.

- 1993b. Wider die Verengung der Rechtfertigungslehre: Der Stellenwert der Rechtfertigung im Kontext biblischer Heilslehren. Jahrbuch Mission 1993 Hamburg: Verband evangelischer Missionskonferenzen, pp 141-171.

- 1997. The Conquest of Chaos: The biblical paradigm of creation and its contemporary relevance. Journal of Theology for Southern Africa 98 / 1997 45-63.

_ 1999a. The exodus - ethnic identity or revolutionary memory? The trajectory of the exodus paradigm in biblical history and its political relevance today. Missionalia 27/1999 20-61.

- 1999b. Sacrifice and Ecology: The trajectory of sacrifice as a soteriological paradigm in biblical history and its relevance for the ecological predicament of modernity. Scriptura, vol 71/1999 279-301.

Räisänen, H 1986. The Torah and Christ. Helsinki: Finish Exegetical Society.

Räisänen, H 1992. Jesus, Paul and Torah: Collected essays. Sheffield: Sheffield Academic Press.

Reventlow, HG 1971. Rechtfertigung im Horizont des Alten Testamentes. München: Kaiser. Reviv, H 1987. The traditions concerning the inception of the legal system in Israel: Significance and dating. ZAW, 1987-4, 566-575.

Roloff, J 1995. Einführung in das Neue Testament. Stuttgart: Reclam.

Sanders EP 1977. Paul and Palestinian Judaism: A comparison of patterns of religion. London: SCM.

Sanders EP 1985. Paul, the law and the Jewish people. London: SCM.

Sanders, EP 1991. Paul. Oxford: Oxford / New York: Univ Press.

Sanders, EP 1992. Judaism: Practice and belief. 63BCE - 66 CE. London: SCM/Philadelphia: Trinity.

Schmid HH 1968. Gerechtigkeit als Weltordnung: Hintergrund und Geschichte des alttestamentlichen Gerechtigkeitsbegriffs. Tübingen: Mohr.

Smend, R 1963. Die Bundesformel. Theologische Studien Heft 68. Zürich: EVZ.

Stuhlmacher, P 1981. Versöhnung, Gesetz und Gerechtigkeit. Göttingen: Vandenhoeck \& Ruprecht, 1980.

Synofzig, E 1977. Die Gerichts- und Vergeltungsaussagen bei Paulus: eine traditionsgeschichtliche Untersuchung. Göttingen: Vandenhoeck \& Ruprecht. 
Theissen, G 1999. A theory of primitive Christian religion. London: SCM.

Thielman, F 1989. From plight to solution: A Jewish framework for understanding Paul's view of the law in Galatians and Romans. Leiden: Brill.

Wallis, G 1980. Torah und Nomos: Zur Frage nach Gesetz und Heil. Theologische Literaturzeitung 105/1980 321-332.

Watson, NM 1983. Justified by faith; judged by works - an antinomy? New Test Studies 29/1983, 209-221.

Wright, NT 1991. The climax of the covenant: Christ and the law in Pauline theology. Edinburgh: T \& T Clark. 